\title{
Stable isotope analyses identify trophic niche partitioning between sympatric terrestrial vertebrates in coastal saltmarshes with differing oiling histories
}

\author{
Sydney Moyo ${ }^{\text {Corresp., } 1,2}$, Hayat Bennadji ${ }^{1}$, Danielle Laguaite ${ }^{1}$, Anna A Perez-Umphrey ${ }^{3}$, Allison M Snider ${ }^{3}$, Andrea \\ Bonisoli-Alquati $^{4}$, Jill A Olin $^{5}$, Philip C Stouffer ${ }^{3}$, Sabrina S Taylor ${ }^{3}$, Paola C López-Duarte ${ }^{6}$, Brian J Roberts ${ }^{7}$, \\ Linda Hooper-Bui ${ }^{8}$, Michael J Polito \\ ${ }^{1}$ Department of Oceanography and Coastal Sciences, Louisiana State University, Baton Rouge, Louisiana, United States of America \\ 2 Department of Biology, Rhodes College, Memphis, Tennessee, United States of America \\ ${ }^{3}$ School of Renewable Natural Resources, Louisiana State University and AgCenter, Baton Rouge, Louisiana, United States of America \\ 4 Department of Biological Sciences, California State Polytechnic University - Pomona, Pomona, California, United States of America \\ 5 Great Lakes Research Center, Michigan Technological University, Houghton, Michigan, United States of America \\ 6 Department of Biological Sciences, University of North Carolina at Charlotte, Charlotte, North Carolina, United States of America \\ 7 Louisiana Universities Marine Consortium, Chauvin, Louisiana, United States of America \\ 8 Department of Environmental Sciences, Louisiana State University, Baton Rouge, Louisiana, United States of America \\ Corresponding Author: Sydney Moyo \\ Email address: sydmoyo@gmail.com
}

Bioindicator species are commonly used as proxies to help identify the ecological effects of oil spills and other stressors. However, the utility of taxa as bioindicators is dependent on understanding their trophic niche and life history characteristics, as these factors mediate their ecological responses. Seaside sparrows (Ammospiza maritima) and marsh rice rats (Oryzomys palustris) are two ubiquitous terrestrial vertebrates that are thought to be bioindicators of oil spills in saltmarsh ecosystems. To improve the utility of these omnivorous taxa as bioindicators, we used carbon and nitrogen stable isotope analysis to quantify their trophic niches at saltmarshes in coastal Louisiana with differing oiling histories. We found that rats generally had lower trophic positions and incorporated more aquatic prey relative to seaside sparrows. The range of resources used (i.e. trophic niche width) varied based on oiling history. Seaside sparrows had wider trophic niches than marsh rice rats at unoiled sites; but not at oiled sites. Trophic niche widths of conspecifics were less consistent at oiled sites, although marsh rice rats at oiled sites had wider trophic niches than rats at unoiled sites. These results suggest that past oiling histories may have imparted subtle, yet differing effects on the foraging ecology of these two co-occurring species. However, the temporal lag between initial oiling and our study makes identifying the ultimate drivers of differences between oiled and unoiled sites challenging. Even so, our findings provide a baseline quantification of the trophic niches of sympatric seaside sparrows and marsh rice rats that will aid in the use of these species as indicators of oiling PeerJ reviewing PDF | (2020:04:48011:1:1:NEW 28 Jan 2021) 
and other environmental stressors in saltmarsh ecosystems. 
1 Stable isotope analyses identify trophic niche partitioning between sympatric terrestrial vertebrates in coastal saltmarshes with differing oiling histories

3

4 Sydney Moyo ${ }^{1,2,}{ }^{*}$, Hayat Bennadji ${ }^{1}$, Danielle Laguaite ${ }^{1}$, Anna A. Perez-Umphrey ${ }^{3}$, Allison M.

5 Snider ${ }^{3}$, Andrea Bonisoli-Alquati ${ }^{4}$, Jill A. Olin ${ }^{5}$, Philip C Stouffer ${ }^{3}$, Sabrina S. Taylor ${ }^{3}$, Paola C. López-

6 Duarte $^{6}$, Brian J. Roberts ${ }^{7}$, Linda Hooper-Bui ${ }^{8}$, Michael J. Polito ${ }^{1}$

7

$8{ }^{1}$ Louisiana State University, Department of Oceanography and Coastal Sciences, Baton Rouge, 9 Louisiana, United States of America

${ }^{2}$ Rhodes College, Department of Biology, Memphis, Tennessee, United States of America

${ }^{3}$ Louisiana State University and AgCenter, School of Renewable Natural Resources, Baton Rouge,

Louisiana, United States of America

${ }^{4}$ California State Polytechnic University, Pomona, Department of Biological Sciences, Pomona,

California, United States of America

${ }^{5}$ Michigan Technological University, Great Lakes Research Center, Houghton, Michigan, United

States of America

${ }^{6}$ University of North Carolina at Charlotte, Department of Biological Sciences, Charlotte, North

Carolina, United States of America

${ }^{7}$ Louisiana Universities Marine Consortium, Chauvin, Louisiana, United States of America

${ }^{8}$ Louisiana State University, Department of Environmental Sciences, Baton Rouge, Louisiana, United States of America

*corresponding author:

Email: sydmoyo@gmail.com 


\section{Abstract}

Bioindicator species are commonly used as proxies to help identify the ecological effects of oil spills and other stressors. However, the utility of taxa as bioindicators is dependent on understanding their trophic niche and life history characteristics, as these factors mediate their ecological responses. Seaside sparrows (Ammospiza maritima) and marsh rice rats (Oryzomys palustris) are two ubiquitous terrestrial vertebrates that are thought to be bioindicators of oil spills in saltmarsh ecosystems. To improve the utility of these omnivorous taxa as bioindicators, we used carbon and nitrogen stable isotope analysis to quantify their trophic niches at saltmarshes in coastal Louisiana with differing oiling histories. We found that rats generally had lower trophic positions and incorporated more aquatic prey relative to seaside sparrows. The range of resources used (i.e. trophic niche width) varied based on oiling history. Seaside sparrows had wider trophic niches than marsh rice rats at unoiled sites; but not at oiled sites. Trophic niche widths of conspecifics were less consistent at oiled sites, although marsh rice rats at oiled sites had wider trophic niches than rats at unoiled sites. These results suggest that past oiling histories may have imparted subtle, yet differing effects on the foraging ecology of these two co-occurring species. However, the temporal lag between initial oiling and our study makes identifying the ultimate drivers of differences between oiled and unoiled sites challenging. Even so, our findings provide a baseline quantification of the trophic niches of sympatric seaside sparrows and marsh rice rats that will aid in the use of these species as indicators of oiling and other environmental stressors in saltmarsh ecosystems.

Keywords: stable isotope analysis, saltmarsh, Ammospiza maritima, Oryzomys palustris 
52

53

54

55

56

57

\section{Introduction}

Large oil spills have devastating effects on wildlife in coastal ecosystems (Ridoux et al., 2004; White et al., 2012; Troisi, Barton \& Bexton, 2016). The Deepwater Horizon Oil Spill (DWH), which lasted for several months, was the largest (> $700000 \mathrm{~m}^{3}$ of crude oil; McNutt et al., 2012) marine oil spill in the history of the United States of America (Crone \& Tolstoy, 2010). This spill resulted in high mortalities of birds, sea turtles, and marine mammals (Antonio, Mendes \& Thomaz, 2011). Additionally, the DWH affected $2113 \mathrm{~km}$ of the Louisiana coastline, including ecologically and economically important coastal marshes (Nixon et al., 2016); coastal wetlands accounted for at least 1,105 km (52\%) of oiled shorelines, 95\% of which were in Louisiana (Nixon et al., 2016). Researchers have documented that oil penetrated into the marsh with zones of oiled plant canopies extending an average of $11 \mathrm{~m}$ from the shoreline, with a maximum penetration distance of 21m (Kokaly et al., 2013; Michel et al., 2013; Zengel et al., 2015). In 2011, oil in some locations was found to have penetrated more than $100 \mathrm{~m}$ into the marsh (Turner et al., 2014b). Studies documenting the effects of stressors such as oil spills, have conventionally focussed on the acute effect rather than the chronic effects on vertebrates (Helm et al., 2015). As species can differ in their response to common stressors, there is a need for studies that investigate the long-term (indirect) effects of stressors on co-occurring species.

Terrestrial vertebrates are commonly used as proxies of contaminant effects in coastal wetland ecosystems (Frederick, Spalding \& Dusek, 2002; Rabalais \& Turner, 2016), because shoreline contamination increases the probability of terrestrial animals being exposed to such contaminants (McCann et al., 2017) particularly because of the depth of penetration of the oil (see Turner et al., 2014b). Seaside sparrows (Ammospiza maritima) and marsh rice rats 
74 (Oryzomys palustris) may be useful bioindicators in saltmarshes along the Northern Gulf of

75 Mexico (reviewed by Bergeon Burns et al., 2014). Both are ubiquitous in these systems, and are 76 generalist omnivores that exhibit high site fidelity (Kern \& Shriver, 2014). Owing to their high

77 fidelity, oiling can have differential effects on Seaside sparrows (hereafter referred to as 'sparrows') and marsh rice rats (hereafter referred to as 'rats') . For example, the DWH oil spill caused sparrow mortality (USFWS, 2011) and altered expression of genes involved in the liver's metabolism of xenobiotics (Perez-Umphrey et al., 2018), as well as liver regeneration and homeostasis (Bonisoli-Alquati et al., 2020). Similarly, the DWH oil spilled resulted in sparrows incorporating carbon from oil into gut contents and newly grown feathers (Bonisoli-Alquati et al., 2016). The DWH oil spill led to decreased insect and arthropod abundances and altered community compositions at oiled sites compared to unoiled sites (Zengel et al., 2015; Husseneder, Donaldson \& Foil, 2016; Bam et al., 2018) possibly leading to increased competition among terrestrial vertebrates for prey at oiled sites (sensu Bergeon Burns et al. 2014). Despite their potential as bioindicators, limited information exists on the trophic niches and trophic interactions of sparrows and rats (although see Olin et al., 2017; Johnson, Olin \& Polito, 2019). bioindicator approaches to be effective (Greenberg et al., 2006). Food web approaches describing the trophic links between organisms can provide information about species-specific behaviors and potential effects of contaminants on co-occurring species in an ecosystem 93 (O’Gorman, Fitch \& Crowe, 2012; Kovalenko, 2019). Trophic niches often differ among co94 occurring species (e.g. Polito et al., 2016; Dionne, Dufresne \& Nozais, 2017) and are influenced by factors such as morphology (Maia-Carneiro, Motta-Tavares \& Rocha, 2017), physiology 
96 (Franco-Trecu, Aurioles-Gamboa \& Inchausti, 2014), foraging strategy (Blanchet-Aurigny et al.,

97 2015), food availability (Akasaka, Nakano \& Nakamura, 2009) and competition (Mwijage, Shilla

98 \& Machiwa, 2018). These factors can lead to interspecific niche partitioning that supports co-

99 existence over time (Hutchinson, 1959; May \& Arthur, 1972; Olin et al., 2020). For example, rats

100 and sparrows use different foraging strategies, with sparrows known to aerially hawk and glean

101 off substrate (e.g. vegetation, marsh sediment, etc.) for their food (Post \& Greenlaw, 2006).

102 Conversely, rats feed on terrestrial and aquatic resources available on the marsh platform

103 (Kruchek, 2004). Sparrows are strictly diurnal while rats are nocturnal (Post, 1981). These

104 different foraging strategies may also lead to different resource use and thus niche partitioning

105 between sparrows and rats. However, no prior study has concurrently examined the trophic

106 niches of these two species in sympatry. Knowledge of resource use and overlap between

107 sympatric species is important not only from an ecological context but also has a significant

108 bearing on assessing the potential effect of future environmental disturbances (sensu Fenton,

109 2003; Hunter et al., 2015). Therefore, an improved understanding of the trophic ecology of

110 sparrows and rats is warranted both to examine the potential for niche partitioning and to

111 improve the use of these species as bioindicators of past and future environmental perturbations

112 (Bergeon Burns et al., 2014; Bonisoli-Alquati et al., 2016, 2020; Olin et al., 2017; Perez-Umphrey

113 et al., 2018).

Stable isotope analysis offers an effective tool for quantifying the trophic ecology of a

wide range of consumers. This approach has been used in past studies to examine the trophic

116 niche of coastal consumers (Blanchet-Aurigny et al., 2015; Zhang et al., 2019), the dietary overlap

117 of co-occurring vertebrate species (Bootsma et al., 1996; Larson, Twardochleb \& Olden, 2017), 
118 and the relative importance of basal carbon sources in consumer food webs (Garcia et al., 2017;

119 Grieve \& Lau, 2018; David et al., 2019). Nitrogen stable isotope values $\left(\delta^{15} \mathrm{~N}\right)$ are commonly used

120 to infer the trophic position of consumers, while carbon stable isotope values $\left(\delta^{13} \mathrm{C}\right)$ can be used

121 to quantify the use of terrestrial vs. aquatic resources (Crawford, Mcdonald \& Bearhop, 2008;

122 Inger \& Bearhop, 2008). Moreover, in combination, $\delta^{13} \mathrm{C}$ and $\delta^{15} \mathrm{~N}$ values act to define a 123 consumer's isotopic niche, a proxy of a consumer's trophic niche, which can be compared across 124 species, time, and space (Bearhop et al., 2004; Newsome et al., 2007).

We used stable isotope analysis to quantify and compare the trophic position, relative importance of terrestrial vs. aquatic resources, and trophic niche width and overlap of cooccurring sparrows and rats at saltmarshes in Barataria Bay, Louisiana. Differing morphologies, physiologies and behaviours often lead co-occurring species to use different resources and occupy separate and unique trophic niches (i.e. niche partitioning; Fink et al., 2012; Karlson,

sparrows and rats occupy similar trophic positions because they are both omnivores; (2) rats incorporate more aquatic prey than sparrows owing to their ground foraging strategies and swimming; (3) sparrows have wider trophic niches compared to rats because sparrows are diurnal and feed both aerially and on the ground, and (4) sparrows and rats exhibit asymmetric niche overlap as a function of their hypothesized similar trophic positions yet differing resource use and trophic niche widths. Specifically, trophic niches of rats will exhibit greater overlap with

137 the trophic niches of sparrows than vice versa. Here, niche overlap is the probability that an 138 individual from one species is found within the total trophic niche of the other species. We considered these four hypotheses across sites with differing oiling histories following the 2010 
140 DWH oil spill, to examine the chronic effects and ecological legacy of the disaster on these

141 species' trophic interactions and species-specific trophic niches.

\section{Material and Methods}

143 Study species and life histories

Seaside sparrows are the most common small passerines ( 15-25g) found in Louisiana coastal marshes (Grenier \& Greenberg, 2006). Sparrows rely on seeds, insects, and other marsh invertebrates (Post \& Greenlaw, 2006). Both sparrows and rats are year-round residents with small home ranges (Cooney, Schauber \& Hellgren, 2015), especially during the breeding season, making them highly susceptible to a wide range of environmental perturbations to coastal marsh ecosystems (e.g. flooding, climate change, sea rise, pollution; Bergeon Burns et al., 2014; Kern \& Shriver, 2014). Of the 1,185 sparrows captured from our study sites between 2011-2017, 79 sparrows were captured in more than one sampling year. While a majority of recaptures occurred one or two years apart ( $n=43,24$ respectively), six birds were captured across a time span of three years while six were captured across a time span of four years. Notably, these sparrows were adults when initially captured, so these birds were likely older than three or four years of age. The oldest wild sparrow recorded was at least nine years old (Sykes Jr., 1980); while this lifespan is likely uncommon, it may be possible that a small number of birds sampled in this study could have been alive during the DWH spill. No nestlings were recaptured as adults during our study. 
Marsh rice rats are mid-sized $(\sim 40-80 \mathrm{~g})$, semi-aquatic cricetid rodents common in

162

163

164

165

166

167

168

169

170

171

172

173

174

175

176

177

178

179

180

181

Louisiana coastal marshes (Wolfe, 1982). Rats are omnivorous and known to consume a range of prey with plants, crabs, insects and molluscs making significant contributions to their diet (Sharp, 1967; Kruchek, 2004). Rat populations are characterized by high turnover rates and rarely live longer than one year, although one individual was documented to live up to two years (Wolfe, 1985). At our study sites, only three rice rats were recaptured over two consecutive field seasons (A. Perez-Umphrey, unpublished data), one in 2014 then in 2015, two in 2016 then in 2017 (although, note, 2014 samples were not included in this present study). Because only subadult and adult rats were bled, and all of these individuals were juveniles in their first year of capture, only a single sample exists for each of these three individuals from when they were recaptured. No individuals sampled would have been present in 2010.

\section{Ethics statement}

All animals (birds, rats, and invertebrates) and plants were sampled on private or public land after obtaining prior permission from owners or managers, and the necessary permits. The capture and handling of all animals was approved by the United States Fish and Wildlife Service (collecting permits MB095918-0 and MB095918-1; USFWS Federal Bird Banding permit 22648; and, Louisiana Department of Wildlife and Fisheries scientific collecting permits LNHP-15-039, LNHP-16-056, LNHP-17-064, LNHP-15-033, LNHP-16-048, LNHP-17-039). All sampling protocols adhered to statutes of the Institutional Animal Care and Use Committee of the LSU AgCenter (IACUC permits: A2013-09, A2015-04, A2016-06).

\section{Study area}



area is either dominated by smooth cordgrass, Spartina alterniflora or less commonly codominated with Juncus roemerianus. This region of Barataria Bay was selected as the focus of this study because it received some of the heaviest oiling following the 2010 DWH oil spill (Michel

et al., 2013; Turner et al., 2014a). We selected seven marsh sites based on their oiling histories

as determined by a combination of systematic methods [Shoreline Clean-up and Assessment Technique (SCAT); Michel et al., 2013] and chemical analyses (Turner et al., 2014a) following the 2010 spill. These seven sites laid the basis for our experimental design in 2015, 2016, and 2017. We categorized sites as either 'oiled' $(n=4)$ or 'unoiled' $(n=3)$ based on the SCAT maps' documented categories of oiling (categories: heavy, moderate, light, very light, trace oiling and no oiling; Turner et al., 2014a) from the marsh edge. Our sites were in Bay Batiste (O2, O3, O4heavily oiled), Bay Sanbois (U1,U2- unoiled), and Bay Jimmy (O1- heavily oiled, U3- unoiled). Sampling plots within sites were 2.5 ha (500 $\mathrm{m}$ along the marsh edge and $50 \mathrm{~m}$ inland) and sites were a minimum of $1 \mathrm{~km}$ apart (Fig. 1). Site classification was confirmed through sediment analyses (Turner et al., 2014a,b) as oiled marsh sites had initial polycyclic aromatic hydrocarbon (PAH) mean \pm standard deviation concentrations of $19524 \pm 2158 \mu \mathrm{g} \mathrm{kg}^{-1}$ (Turner et al., 2014a) and unoiled sites had initial (PAH) mean \pm standard deviation concentrations of $164 \pm 21 \mu \mathrm{gg}^{-1}$ (Ashton-Meyer, 2017). Although our study started five years after initial oiling when oiling effects may have attenuated, we explicitly explored these comparisons to test for chronic and/or indirect effects because oil can persist in marsh habitats over long periods of time (Turner et al., 2019). 
Rats were caught in baited Sherman live traps set overnight. Sparrows were caught in

205

206

207

208

209

mist nets (34 mm mesh, $12 \mathrm{~m}$ length). All rats and sparrows captured were weighed sexed, and aged. Aging of sparrows and rats ensured that only adults and sub-adults were sampled (i.e. juveniles were excluded from all subsequent analyses). Blood samples were drawn from sparrows and rats via venipuncture of the brachial vein and retro-orbital sampling, respectively. All blood samples were transferred to glass vials and stored frozen until further analysis.

collected off the marsh edge through a 105-micron screen to remove large zooplankton and inorganic particulates and onto combusted glass fibre filters (Whatman GF/F). We confirmed that we retained most of the phytoplankton community with this approach by analysing chlorophyll$a$ concentration on screened and unscreened samples. Chlorophyll- $a$ concentrations on screened samples were $>85 \%$ of total chlorophyll- $a$ on unscreened samples (and over $90 \%$ in most cases; B. Roberts, unpublished data). Gulf ribbed mussels (Geukensia granossissima) were collected by hand from the marsh surface. Samples of the dominant marsh vegetation (i.e. Spartina alterniflora) were collected along with herbivorous terrestrial Hemiptera (Prokelisia spp and Ischnodemus spp) by hand and using sweep nets. These primary producers and primary consumer samples provided isotopic proxies of the dominant aquatic and terrestrial marsh energy pathways, respectively. Muscle tissue was dissected from ribbed mussels, whole bodies were retained for insects, and all samples were frozen in the field prior to analysis.

Stable isotope analysis 
dried POM samples were removed from filters and placed into tin capsules for stable isotope analysis. Samples were flash combusted using a Costech ECS4010 Elemental Analyzer and according to the following equation:

$$
\delta X=\left[\left(R_{\text {sample }} / R_{\text {standard }}\right)-1\right] \times 1000
$$
values are referenced to the Vienna PeeDee Belemnite (VPDB) for $\delta^{13} \mathrm{C}$ and atmospheric $\mathrm{N}_{2}$ for $\delta^{15} \mathrm{~N}$

Raw $\delta$ values were normalized on a two-point scale using glutamic acid reference materials with low and high values [i.e. USGS40 $\left(\delta^{13} \mathrm{C}=-26.4 \%, \delta^{15} \mathrm{~N}=-4.5 \%\right.$ ) and USGS41 $\left(\delta^{13} \mathrm{C}\right.$ $=37.6 \%$ o, $\delta^{15} \mathrm{~N}=47.6 \%$ )]. The analytical precision, based on standard deviations of repeated reference materials were $0.1 \%$ and $0.2 \%$ for $\delta^{13} \mathrm{C}$ and $\delta^{15} \mathrm{~N}$, respectively.

\section{Data analyses}

We performed a three-way analysis of similarities (ANOSIM), which permits unbalanced replication between treatments (Clarke \& Gorley, 2006), to describe differences in the isotope values of basal end members and primary consumers. Taxa, year, and treatment (site) were classified as factors in all analyses and resemblance matrices were based on Euclidean distances (9999 permutations). ANOSIM, a non-metric multivariate statistical method, has no underlying 
245

246 247 (Clarke \& Gorley, 2006). ANOSIM results in an R-value and a p-value. The R-value is scaled from

assumptions about the statistical distribution of the data (e.g. normality, variance equality) and creates an overall test statistic (R) that indicates if differences among taxa, sites and years exist -1 to +1 . $R$-values $=0$ indicate random grouping, $R \geq 0.3$ shows that groups are slightly different but overlapping, and $R \geq 0.5$ indicates well separated groups (Clarke \& Gorley, 2006).

We calculated trophic position (TP) of sparrows and rats using Bayesian models using mode for TP estimates in the tRophicPosition package (Quezada-Romegialli et al., 2018) in the statistical software R (version 3.5.0; R Core Team, 2019). This approach couples Markov Chain Monte Carlo simulations with stable isotope data to estimate TP. Because TPs calculated from Bayesian models display higher uncertainty with smaller sample size (Quezada-Romegialli et al., 2018), and low samples sizes were present in some species, site, and year combinations, we pooled data across all oiled and unoiled sites, respectively. In all TP calculations, we set the model parameters as follows: baseline $=$ 'twobaselinesfull', iterations $=100000$, number of chains ( $\mathrm{n}$. chains) $=5$ and 'burn-in' (number of initial iterations discarded) $=20000$. We used the stable isotope values $\left(\delta^{13} \mathrm{C} ; \delta^{15} \mathrm{~N}\right)$ of ribbed mussels and herbivorous insects as representative of aquatic and terrestrial food web baselines, respectively. To validate our assumption that primary consumers were representative of aquatic and terrestrial resources, we visually compared them to the stable isotope values of POM and marsh vegetation (i.e. Spartina alterniflora; Fig. 2). We then used tRophicPosition to quantify the relative importance of terrestrial and aquatic food resources $(\alpha)$ to rats and sparrows, with larger $\alpha$ values implying greater use of terrestrial relative to aquatic food resources. We calculated TP and $\alpha$ separately for each species, site, and year combination and all models incorporated an assumed mean trophic fractionation $\left(\Delta^{13} C=0.39 \pm\right.$ 
267 1.30; $\Delta^{15} \mathrm{~N}=3.4 \pm 0.98$ ) per trophic transfer (Post, 2002). TP and $\alpha$ metrics are presented as modal

268 values. Associated 95\% credibility intervals $(\mathrm{Cl})$ and Bayesian posterior probabilities (PP > 0.95)

269 from pairwise comparisons of posterior distributions of TP and alpha ( $\alpha$ ), which were used to

270 indicate statistically significant differences across species, site, and year combinations. Pairwise

271 comparisons among years between and within species were expressed as Bayesian posterior

272 probabilities (PP> 0.95) to test for significant differences among groups. We pooled data across

273 all oiled and unoiled sites for sparrows and rats. We used this approach for three reasons: first,

274 preliminary analyses revealed that there were similar trends between pooled and site-specific

275 analyses (Table S1). Second, our analyses are sensitive to sample sizes, as such, it was necessary

276 to combine samples to avoid bias (Jackson et al., 2011; Quezada-Romegialli et al., 2018). Third,

277 pooling samples into 'oiled' and unoiled' categories would allow us to make direct comparisons

278 of overall differences between previously oiled and unoiled sites.

We quantified the trophic niche width of sparrows and rats using the Stable Isotope

Bayesian Ellipses in R (SIBER) package version 2.1.4 (Jackson et al., 2011). We visualized trophic niches using the standard ellipse area corrected for sample size $\left(\mathrm{SEA}_{c}\right)$ represented by the bivariate standard deviation of $\delta^{13} \mathrm{C}$ and $\delta^{15} \mathrm{~N}$ values, encompassing approximately $40 \%$ of the data (Jackson et al., 2011). Moreover, we compared the Bayesian approximation of standard ellipse area $\left(\mathrm{SEA}_{b}\right)$ between groups as a quantitative measure of isotopic trophic niche width. Because $\mathrm{SEA}_{b}$ display higher uncertainty with smaller sample size (Jackson et al., 2011), and low samples sizes were present in some species, site, and year combinations, we pooled data across oiled and unoiled sites prior to analyses similar to our analysis of TP. Values for SEA $\mathrm{A}_{b}$ are reported 
288

289

290

291

292

293

294

295

as modal values with $95 \% \mathrm{Cl}$ and Bayesian posterior probabilities ( $\mathrm{PP}>0.95$ ) were used to test for significant differences among groups.

To quantify overlap in resource use (i.e. trophic niche overlap) among species and between sites, we quantified the proportional overlap between Bayesian-estimated standard ellipses $\left(S E A_{b}\right)$ of each group using nicheROVER package 1.0 (Swanson et al., 2015). As in analysis of SEA $\mathrm{A}_{\mathrm{b}}$ area, we pooled data into oiled and unoiled sites prior to analyses. Trophic niche overlap is defined as the probability that an individual from one species is found within the total trophic niche of the other species with values ranging from $0 \%$ (no overlap) to $100 \%$ (complete overlap). We considered trophic niche overlap to be asymmetrical when $95 \% \mathrm{Cl}$ did not overlap among reciprocal comparisons of $\mathrm{Cl}$, such that individuals in one group are significantly more likely to be encompassed in the ellipses of another group than vice versa.

\section{Results}

\section{Summary of basal endmembers and primary consumers}

Biplot of $\delta^{13} \mathrm{C}$ and $\delta^{15} \mathrm{~N}$ and ANOSIM revealed clear separations between POM and Spartina alterniflora (Fig. 2; Global $\mathrm{R}=1.0, \mathrm{p}=0.001$ ) with no significant differences in stable isotope values by treatment [oiled sites versus unoiled sites; ANOSIM, Global R=0.1, $p=0.23$ ] or year $(\mathrm{ANOSIM}=0.1, \mathrm{p}=0.13) \cdot \delta^{15} \mathrm{~N}$ values of $\mathrm{POM}$ (range $=4.3$ to $8.6 \%$ ) were higher than Spartina alterniflora (range $=1.7$ to $5.8 \%$ ). Conversely, $\delta^{13} \mathrm{C}$ values in POM (range=-24.4 to $22.2 \%$ ) were lower than Spartina alterniflora (range=-13.6 to $-11.8 \%$ ).

Biplot of $\delta^{13} \mathrm{C}$ and $\delta^{15} \mathrm{~N}$ and ANOSIM also revealed clear separations between hemipterans and ribbed mussel (Fig. 2; ANOSIM, Global R=0.9, $\mathrm{p}=0.001$ ). Ribbed mussels (aquatic baseline) 
309

310

311

312

313

314

315

316

317

318

319

320

321

were similar across all sites (ANOSIM, Global $\mathrm{R}=0.3, \mathrm{p}=0.02$ ) and year (ANOSIM, Global $\mathrm{R}=0.2$, $p=0.4$ ). Similarly, hemipterans (terrestrial baseline) did not vary by site (ANOSIM, Global $R=0.0$, $p=0.2$ ) or year (ANOSIM, Global $R=0.0, p=0.5$ ). Stable isotope values of ribbed mussels (aquatic baseline; $\delta^{13} \mathrm{C}$ range $=-23.7$ to $-19.2 \%$; $\delta^{15} \mathrm{~N}$ range $=5.2$ to $7.8 \%$ ) and hemipterans (terrestrial baseline; $\delta^{13} \mathrm{C}$ range $=-14.0$ to $-11.2 ; \delta^{15} \mathrm{~N}$ range $=3.3$ to 6.5 ) plotted closely to POM and Spartina alterniflora, respectively.

\section{Trophic position [Hypothesis 1]}

Trophic position for sparrows and rats ranged between 2.5 to 3.1 (modal values; Table 1).

TP was higher in sparrows than rats at both oiled and unoiled sites in 2016 and 2017, and at oiled sites in 2015 (Table 1; Fig. 3). Trophic positions of sparrows did not differ between oiled and unoiled sites in any year examined (Table 1; Table S2; Fig. 2). Similarly, TP of rats did not differ between oiled and unoiled sites in any year examined (Table 1; Table S2; Fig. 3).

\section{Resource use [Hypothesis 2]}

Sparrows consistently relied on terrestrial resources to a greater degree than aquatic resources (i.e. mode $\alpha>50 \%$; Fig. 3; Table 1 ) in all three years sampled. Rats relied more on terrestrial resources than aquatic resources in 2015. Conversely, in 2016 and 2017 rats assimilated more aquatic prey than terrestrial prey. (Fig. 3; Table 1). Considering resource use between rats and sparrows, the use of terrestrial prey resources relative to aquatic prey resources $(\alpha)$ did not differ between sparrows and rats in 2015; however, in 2016 and 2017 rats incorporated more aquatic prey resources (i.e. lower $\alpha$ ) relative to sparrows irrespective of the oiling history of sites (Fig. 3; Table 1; Table S3). 

differences in $\alpha$ were observed in some comparisons between oiled and unoiled sites in both sparrows and rats (Table 1; Table S3). Specifically, modal $\alpha$ values of sparrows were higher at oiled sites than unoiled sites in 2015 and 2017 but were similar in 2016 (Table 1). Modal $\alpha$ values of rats at oiled sites were greater than those at unoiled sites in 2015 but were similar in 2016 and 335 2017 (Table 1).

Trophic niche width [Hypothesis 3]

Sparrows had larger isotopic niche widths $\left(\mathrm{SEA}_{b}\right)$ than rats at unoiled sites in all three years, and at oiled sites only in 2015 (Table 1; Fig. 3). Sparrows had smaller trophic niche widths $\left(\mathrm{SEA}_{\mathrm{b}}\right)$ at oiled sites relative to unoiled sites in 2016 and 2017 (Table 1; Fig. 3). In contrast, rats at oiled sites had consistently larger trophic niche widths $\left(S E A_{b}\right)$ relative to rats at unoiled sites in all three years examined (Table 1; Fig. 3; Table S4).

\section{Trophic niche overlap [Hypothesis 4]} at both oiled and unoiled sites (Fig. 4); with 2016 and 2017 showing minimal overlap between rats and sparrows at oiled and unoiled sites. When comparing niche overlap within species (rats vs rats, sparrows vs sparrow), trophic niche overlap within species was higher in 2016 and 2017 relative to 2015 for both sparrows and rats (Fig. 4). 
351 2). However, at oiled sites the direction and consistency of asymmetric trophic niche overlap

352 differed across years. For example, at oiled sites in 2015, rats exhibited larger niche overlap (95\%

$353 \mathrm{Cl}: 71-93 \%)$ relative to sparrows, than vice versa (95\% Cl: $49-70 \%$; Table 2$)$. In contrast, at oiled

354 sites in 2017 sparrows exhibited larger niche overlap (95\% Cl: 39-80\%) relative to rats, than vice

355 versa (95\% Cl:34-66\%; Table 2). Trophic niche overlap between species was symmetrical at oiled

356 sites in 2015 (Table 2).

357

358

359

\section{Discussion}

In coastal marsh ecosystems, the feeding ecology of terrestrial omnivores are often

flexible and dependent on environmental conditions (Ruiter, Wolters \& Moore, 2005) similar to

freshwater ecosystems (Hellmann, Wissel \& Winkelmann, 2013). The possible effects of

environmental stressors on the trophodynamics of terrestrial vertebrates in coastal marshes are poorly understood (sensu Olin et al., 2017). This study presents insights into the foraging ecology,

niche partitioning, and possible influence of oiling history on two ubiquitous vertebrates (the

seaside sparrow and the marsh rice rat) in coastal saltmarshes of Louisiana. We observed a

general pattern of interspecific differences in trophic position and aquatic vs. terrestrial resource

use by between sparrows and rat, likely due to their disparate morphologies and foraging behaviours. We found intraspecific differences in trophic niche width as well as variation in the degree and direction of trophic niche overlap and asymmetry between species with differing site oiling histories. 
373 to 3.1; year $=2015,2016$ and 2017) estimated in our study were lower than mean values

374 calculated in a prior study (year $=2013$ and 2014$)$ in coastal Louisiana $(3.5 \pm 0.2$ and $3.8 \pm 0.2$

375 across sites; Olin et al., 2017). The difference in trophic position between our study and the Olin

376 et al., 2017 study, could be attributed to differences in tissues analysed (i.e. blood versus liver),

377 discrimination factors used $\left(\Delta^{13} \mathrm{C}=0.39 \% ; \Delta^{15} \mathrm{~N}=3.4 \%\right.$ in this study versus $\Delta^{13} \mathrm{C}=-0.5 \% ; \Delta^{15} \mathrm{~N}$

$378=3.0 \%$ used in the Olin et al. 2017 study), and differences in the isotope values of aquatic $\left(\delta^{13} \mathrm{C}\right.$

$379=-22.4 \%$; $\delta^{15} \mathrm{~N}=7.2 \%$ in this study versus $\delta^{13} \mathrm{C}=-24.3 \%$; $\delta^{15} \mathrm{~N}=7.4 \%$ o in Olin et al. 2017) and

380 terrestrial baselines $\left(\delta^{13} \mathrm{C}=-12.2 \%\right.$; $\delta^{15} \mathrm{~N}=4.1 \%$ in this study versus $\delta^{13} \mathrm{C}=-12.4 \%$; $\delta^{15} \mathrm{~N}=4.9 \%$ 。

381 in the Olin et al. 2017 study). Few studies have sought to estimate the trophic position of rats.

382 Even so, rats have been proposed to feed on similar food items and thus occupy a similar trophic

383 position as sparrows (sensu Post, 1981). Our results suggest that rats occupy a slightly, but

384 significantly, lower trophic position (2.5 to 2.8 ) relative to sparrows across the study region.

Overall, the largest temporal shifts in trophic position were observed in rats (whereby rats

always occupied lower trophic positions than sparrows), suggesting that while rats are

omnivorous, their omnivory changes over space and time. Temporal omnivory has been

suggested as a key factor in maintaining ecological stability (Kratina et al., 2012). Temporal

omnivory, whereby consumers incorporate prey from lower trophic levels into their diet when

preferred prey become rare, slightly increases stability relative to the case of fixed omnivory

391 (Krivan \& Diehl, 2005). Such shifts in omnivory have been documented in freshwater (Nakano \&

Murakami, 2001) and desert vertebrates (Soykan \& Sabo, 2009). Remaining questions include environmental perturbations. 
Rats consumed a mixture of terrestrial and aquatic prey (Fig. 3), but generally consumed

prior studies that suggest rats are omnivores that prefer aquatic organisms (Sharp, 1967) but are opportunistic feeders that shift their diet to utilize available resources (e.g., seeds and herbaceous plant parts, insects, and dicot vegetation; Rose \& McGurk, 2006). The isotopic trophic niche of sparrows suggests they consume mainly terrestrial organisms, although they do access aquatic-derived prey resources as well. This is in agreement with the findings of other studies

(Olin et al., 2017; Johnson, Olin \& Polito, 2019), which indicate that sparrows in coastal Louisiana commonly forage on $\mathrm{C}_{4}$ plant-consuming insects, as evidenced by stable isotope values typical of

$\mathrm{C}_{4}$ plants (Fig. 2; Wainright et al., 2000; Wigand et al., 2007). Our results agree with these prior studies and suggest that between 2015 and 2017 sparrows at our study area fed predominantly

in a food-web based on plant and animal matter supported by Spartina alterniflora (Post \& Greenlaw, 2006).

Sparrows exhibited wider trophic niches relative to rats at unoiled sites in all three years, and at oiled sites in 2015 only (hypothesis 3). This finding is compatible with the idea that sparrows, which glean food off both vegetation and the marsh sediment (Post \& Greenlaw, 2006), usually exploit a broader range of prey resources relative to sympatric rats. This concept was confirmed by the partial support for our fourth hypothesis. Specifically, asymmetric trophic niche overlap was observed at unoiled sites in all three years. The trophic niche of rats overlapped to 414 a much greater degree with those of sparrows (67.3 to $99.8 \%)$ at unoiled sites, than vice versa 415 (18.7 to 43.5\%). This suggests trophic niches are not fully segregated between these species despite observed differences in trophic position and resource use. In addition, given the wider 
417 trophic niches of sparrows relative to rats, there is a higher potential for rats to compete for food

418

419

420

421

422

423

424

425

426

427

428

429

430

431

432

433

434

435

436

437

438

resources with sparrows, than vice versa. Even so, differences in trophic niche width as well as variation in the degree and direction of trophic niche overlap and asymmetry between species was less consistent at oiled sites. The difference in trophic niches could be ascribed to inter- and intraspecific competition, which are known as major factors in determining the trophic niche width of coexisting species (MacArthur, 1972; Kroetz, Drymon \& Powers, 2017; Arribas, Touchon \& Gomez-Mestre, 2018). Density-dependent effects can also influence trophic overlap among coexisting species (van Beest et al., 2014); however, there were no statistically significant differences in marsh rice rat density in 2015, 2016, and 2017 (Hart, unpublished data), nor between oiled and unoiled sites (Hart, unpublished data; A. Perez-Umphrey, unpublished data).

An additional goal of our study was to compare the trophic niches of sparrows and rats between and within species at sites with differing oiling histories to examine the ecological legacy of the 2010 DWH oil spill. Sample collection for our study (2015-2017) took place approximately five to seven years after the 2010 DWH oil spill. This lag and other factors (see below) makes identifying the proximate drivers of observed differences between oiled and non-oiled sites challenging. The re-distribution of oil following Hurricane Isaac and the confounding effect of bay (Sansbois versus Batiste) i.e. habitat are also major problems that should be acknowledged. I would be inclined to de-emphasize the effect of initial oiling. Regardless, we observe differences in trophic niche metrics between oiled and unoiled sites. For example, sparrows at oiled sites consumed more terrestrial prey resources (larger $\alpha$ values) than sparrows at unoiled sites in two out of the three sampling years. Similarly, rats at oiled sites consumed more terrestrial prey resources (larger $\alpha$ values) than rats at unoiled sites in 2015. In addition, rats had consistently 
439 larger trophic niche widths $\left(S E A_{b}\right)$ at oiled sites relative to unoiled sites in all three years.

440 According to optimal foraging theory, niche width will increase as the availability of specific

441 resources decreases (MacArthur \& Pianka, 1966; Svanbäck \& Bolnick, 2005). Therefore, wider

442 trophic niches of rats and the increased use of terrestrial prey resources at oiled sites could be

443 explained by a decrease in aquatic prey resources preferred by rats. For example, using a meta-

444 analysis approach, Zengel et al., (2015) found evidence that the DWH oil spill suppressed

445 populations of aquatic organisms like fiddler crabs, a common diet item of rats, in oiled marshes

446 with incomplete recovery as of 2014.

Isotopic niche widths of rats were higher at oiled sites compared to rats at unoiled sites

(Fig. 4). The increase in niche width may show the subtle chronic effects of food web dynamics

whereby the foraging behaviour of rats shifts to generalism (i.e. a niche expansion) at oiled sites;

possibly in response to changes in prey availability/diversity. Researchers have reported

persistent effects several years after the DWH oil spill whereby there were significant declines in diversity of marsh meiofauna and macrofauna (Fleeger et al., 2015, 2019), arthropods (Bam et

diversity and prey availability due to oil are not only limited to salt marshes but extend to other ecosystems. The Cosco Busan oil spill revealed that herring embryos that were directly exposed

to oil and those at adjacent sites (but were unoiled) were significantly impacted by oil. Impacts on embryos at the sites were cardiac toxicity (sublethal) whereas impacts on embryos at adjacent sites was tissue death (Incardona et al., 2012). These data reveal an organism doesn't have to be present in an acutely oiled sites to have negative impacts from the oil. Seven years after the 
461 fecundity and larval output) of deep sea megafauna (McClain, Nunnally \& Benfield, 2019).

462 Elsewhere, four years after the DWH oil spill, oiled sites still exhibited depressed meiofaunal and

463 macrofaunal diversity compared to unoiled sites (Reuscher et al., 2017). Further, monitoring of

464 corals from 2010 to 2017 showed the majority of colonies exposed to oil had still not recovered

465 by 2017 (Girard \& Fisher, 2018) and it would take up to three decades for recovery from the DWH

466 oil spill (Girard, Shea \& Fisher, 2018). Taken together these studies suggest a lasting impact on

467 faunal communities and a need to not only assess acute effects (as is common in studies of oil

468 spills) but concomitantly study chronic indirect effects concomitantly with acute effects. Our

469 results support the call by other researchers for long term monitoring of communities affected

470 by DWH oiling effects in the Gulf of Mexico (McClain, Nunnally \& Benfield, 2019).

471 Post-spill declines in the abundance of terrestrial invertebrates, such as insects and

472 spiders, also were reported for Louisiana marshes after the DWH oil spill (McCall \& Pennings,

473 2012; Pennings, McCall \& Hooper-Bui, 2014; Husseneder, Donaldson \& Foil, 2016). However,

474 significant temporal, spatial, and taxon-specific variation in post-spill responses and recovery

475 across studies and the potential for re-distribution of DWH oil by hurricanes (McCall \& Pennings,

476 2012; Bam et al., 2018) likely confound comparisons of the availability of terrestrial resources to

477 sparrows and rats in our study. Specifically, Hurricane Isaac in 2012 is thought to have

478 remobilized and redistributed oil that was deposited in inshore and offshore sediments such that

479 some coastal locations that were initially oil-free became contaminated with petroleum 480 hydrocarbons (Turner et al., 2019). In addition, oiling history is not the only factor that is likely to

481 contribute to spatial and temporal differences in the trophic ecology of these two species. For

482 instance, Olin et al. (2017) used stable isotope and fatty acid analysis to determine that marsh 
483 flooding due to Hurricane Isaac in 2012 had a stronger influence on the diets of sparrows than 484 oiling status. Moreover, additional factors not examined here such as saltmarsh plant community 485 composition, plant cover and biomass as well as elevation, inundation, and other hydrological 486 aspects are likely to influence prey availability in combination with, or independent of, oiling 487 histories (Crosby et al., 2016; Olin et al., 2017; Boesch, 2020).

488

490

491

492

493

494

495 496

\section{Conclusions and additional considerations}

Our study identified a general pattern of interspecific trophic niche partitioning between rats and sparrows co-occurring within saltmarshes in coastal Louisiana. While we observed differences in trophic position and resources use, trophic niches were not fully segregated between rats and sparrows, with asymmetrical overlap between rats and sparrows. When comparing between sites with differing oiling histories we found both interspecific and intraspecific differences in the trophic niche width and the consumption of terrestrial vs. aquatic prey resources, although identifying the proximate causes of these differences are beyond the scope of this study. In addition, because trophic dynamics and environmental processes may be specific to individual sites or regions, the extension of our findings to other saltmarshes should be approached with some caution (Nelson, Deegan \& Garritt, 2015). Even so, our findings provide reference information on respective trophic niche of sparrows and rats that will aid in the evaluation of these species as bioindicators of oiling and other environmental stressors. 
501 Acknowledgments

502 We thank R. Strecker-Lau, W. Bam, K. Kjos, S. Wendt, M. Arias, M. Hart, S. T. Williams, J.

503 Nierman, L. DiNunzio, S. Woltmann, A. Rietl, A. Chelskey, T. Hill, B. Kelly, C. Bourgeois, B. Kelly

504 and S. Setta for field and laboratory assistance.

505 References

506 Akasaka T, Nakano D, Nakamura F. 2009. Influence of prey variables, food supply, and river restoration

507

508

509

510

511

512

513

514

515

516

517

518

519

520

521

522 on the foraging activity of Daubenton's bat (Myotis daubentonii) in the Shibetsu River, a large lowland river in Japan. Biological Conservation 142:1302-1310. DOI:

10.1016/j.biocon.2009.01.028

Antonio FJ, Mendes RS, Thomaz SM. 2011. Identifying and modeling patterns of tetrapod vertebrate mortality rates in the Gulf of Mexico oil spill. Aquatic Toxicology 105:177-179. DOI: 10.1016/j.aquatox.2011.05.022.

Arribas R, Touchon JC, Gomez-Mestre I. 2018. Predation and Competition Differentially Affect the Interactions and Trophic Niches of a Neotropical Amphibian Guild. Frontiers in Ecology and Evolution 6. DOI: 10.3389/fevo.2018.00028.

Ashton-Meyer B. 2017. Analytical support of the Coastal Waters Consortium: Target alkane and aromatic concentrations for sediment samples collected in 2010-2014. Gulf of Mexico Research Initiative Information and Data Cooperative (GRIIDC), Harte Research Institute Texas A\&M UniversityCorpus Christi. DOI: doi:10.7266/N7028PZZ.

Bam W, Hooper-Bui LM, Strecker RM, Adhikari PL, Overton EB. 2018. Coupled effects of oil spill and hurricane on saltmarsh terrestrial arthropods. PLOS ONE 13:e0194941. DOI:

10.1371/journal.pone.0194941.

Peer] reviewing PDF | (2020:04:48011:1:1:NEW 28 Jan 2021) 
523 Bearhop S, Adams CE, Waldron S, Fuller RA, Macleod H. 2004. Determining trophic niche width: a novel

524 approach using stable isotope analysis. Journal of Animal Ecology 73:1007-1012. DOI:

525 10.1111/j.0021-8790.2004.00861.x.

526

527

528

529

530

531

532

533

534

535

536

537

538

539

540

541

542

543

544

545

546

van Beest FM, McLoughlin PD, Vander Wal E, Brook RK. 2014. Density-dependent habitat selection and partitioning between two sympatric ungulates. Oecologia 175:1155-1165. DOI: 10.1007/s00442-014-2978-7.

Bergeon Burns CM, Olin JA, Woltmann S, Stouffer PC, Taylor SS. 2014. Effects of Oil on Terrestrial Vertebrates: Predicting Impacts of the Macondo Blowout. BioScience 64:820-828. DOI: 10.1093/biosci/biu124.

Blanchet-Aurigny A, Dubois S, Quéré C, Guillou M, Pernet F. 2015. Trophic niche of two co-occurring ophiuroid species in impacted coastal systems, derived from fatty acid and stable isotope analyses. Marine Ecology Progress Series 525:127-141. DOI: 10.3354/meps11169.

Boesch DF. 2020. Managing Risks in Louisiana’s Rapidly Changing Coastal Zone. In: Laska S ed. Louisiana's Response to Extreme Weather: A Coastal State's Adaptation Challenges and Successes. Extreme Weather and Society. Cham: Springer International Publishing, 35-62. DOI: 10.1007/978-3-030-27205-0_2.

Bonisoli-Alquati A, Stouffer PC, Turner RE, Woltmann S, Taylor SS. 2016. Incorporation of Deepwater Horizon oil in a terrestrial bird. Environmental Research Letters 11:114023. DOI: 10.1088/1748$9326 / 11 / 11 / 114023$

Bonisoli-Alquati A, Xu W, Stouffer PC, Taylor SS. 2020. Transcriptome analysis indicates a broad range of toxic effects of Deepwater Horizon oil on Seaside Sparrows. The Science of the Total Environment 720:137583. DOI: 10.1016/j.scitotenv.2020.137583.

Bootsma HA, Hecky RE, Hesslein RH, Turner GF. 1996. Food Partitioning Among Lake Malawi Nearshore Fishes as Revealed by Stable Isotope Analyses. Ecology 77:1286-1290. DOI: 10.2307/2265598. 
547 Clarke K, Gorley RN. 2006. Primer v6: User Manual/Tutorial.

548 Cooney SA, Schauber EM, Hellgren EC. 2015. Ranging behavior of marsh rice rats in a southern Illinois 549 wetland complex. Journal of Mammalogy 96:732-741. DOI: 10.1093/jmammal/gyv069.

550 Crawford K, Mcdonald RA, Bearhop S. 2008. Applications of stable isotope techniques to the ecology of 551 mammals. Mammal Review 38:87-107. DOI: 10.1111/j.1365-2907.2008.00120.x.

552 Crone TJ, Tolstoy M. 2010. Magnitude of the 2010 Gulf of Mexico Oil Leak. Science 330:634-634. DOI:

553

554

555

556

557

558

559

560

561

562

563

564

565

566

567

568

569

570 10.1126/science.1195840.

Crosby SC, Sax DF, Palmer ME, Booth HS, Deegan LA, Bertness MD, Leslie HM. 2016. Salt marsh persistence is threatened by predicted sea-level rise. Estuarine, Coastal and Shelf Science 181:93-99. DOI: 10.1016/j.ecss.2016.08.018.

David F, Marchand C, Thành-Nho N, Truong Van V, Taillardat P, Meziane T. 2019. Trophic relationships and basal resource utilisation in the Can Gio Mangrove Biosphere Reserve (Southern Vietnam). Journal of Sea Research 145:35-43. DOI: 10.1016/j.seares.2018.12.006.

Deis DR, Fleeger JW, Johnson DS, Mendelssohn IA, Lin Q, Graham SA, Zengel S, Hou A. 2020. Recovery of the salt marsh periwinkle (Littoraria irrorata) 9 years after the Deepwater Horizon oil spill: Size matters. Marine Pollution Bulletin 160:111581. DOI: 10.1016/j.marpolbul.2020.111581.

Dionne K, Dufresne F, Nozais C. 2017. Overlapping trophic niches among co-occurring amphipods from a cryptic species complex. Freshwater Biology 62:1052-1062. DOI: 10.1111/fwb.12924.

Fenton MB. 2003. Science and the Conservation of Bats: Where to Next? Wildlife Society Bulletin 31:615. DOI: $10.2307 / 3784355$.

Fink P, Reichwaldt E, Harrod C, Rossberg A. 2012. Determining trophic niche width: an experimental test of the stable isotope approach. Oikos 121:1985-1994.

Fleeger JW, Carman KR, Riggio MR, Mendelssohn IA, Lin QX, Hou A, Deis DR, Zengel S. 2015. Recovery of salt marsh benthic microalgae and meiofauna following the Deepwater Horizon oil spill linked to 
recovery of Spartina alterniflora. Marine Ecology Progress Series 536:39-54. DOI:

572 10.3354/meps11451.

573 Fleeger JW, Riggio MR, Mendelssohn IA, Lin Q, Deis DR, Johnson DS, Carman KR, Graham SA, Zengel S,

574

575

576

577

578

579

580

581

582

583

584

585

586

587

588

589

590

591

592

593

Hou A. 2019. What Promotes the Recovery of Salt Marsh Infauna After Oil Spills? Estuaries and Coasts 42:204-217. DOI: 10.1007/s12237-018-0443-2.

Franco-Trecu V, Aurioles-Gamboa D, Inchausti P. 2014. Individual trophic specialisation and niche segregation explain the contrasting population trends of two sympatric otariids. Marine Biology 161:609-618. DOI: 10.1007/s00227-013-2363-9.

Frederick PC, Spalding MG, Dusek R. 2002. Wading birds as bioindicators of mercury contamination in Florida, USA: Annual and geographic variation. Environmental Toxicology and Chemistry 21:163167. DOI: $10.1002 /$ etc. 5620210123.

Garcia AM, Claudino MC, Mont'Alverne R, Pereyra PER, Copertino M, Vieira JP. 2017. Temporal variability in assimilation of basal food sources by an omnivorous fish at Patos Lagoon Estuary revealed by stable isotopes (2010-2014). Marine Biology Research 13:98-107. DOI: 10.1080/17451000.2016.1206939.

Girard F, Fisher CR. 2018. Long-term impact of the Deepwater Horizon oil spill on deep-sea corals detected after seven years of monitoring. Biological Conservation 225:117-127. DOI: 10.1016/j.biocon.2018.06.028.

Girard F, Shea K, Fisher CR. 2018. Projecting the recovery of a long-lived deep-sea coral species after the Deepwater Horizon oil spill using state-structured models. Journal of Applied Ecology 55:18121822. DOI: $10.1111 / 1365-2664.13141$.

Greenberg R, Maldonado JE, Droege S, McDonald MV. 2006. Tidal marshes: A global perspective on the evolution and conservation of their terrestrial vertebrates. BioScience 56:675-685.

Peer) reviewing PDF | (2020:04:48011:1:1:NEW 28 Jan 2021) 
594 Grenier JL, Greenberg R. 2006. Trophic adaptations in sparrows and other vertebrates of tidal marshes.

595 In: Greenberg RS, Maldonado JE, Droege S, McDonald MV eds. Terrestrial Vertebrates of Tidal

596 Marshes: Evolution, Ecology, and Conservation. Camarillo, CA: Cooper Ornithological Society,

$597 \quad 130-140$.

598 Grieve A, Lau DCP. 2018. Do autochthonous resources enhance trophic transfer of allochthonous organic 599 matter to aquatic consumers, or vice versa? Ecosphere 9:e02307. DOI: 10.1002/ecs2.2307.

600 Hellmann C, Wissel B, Winkelmann C. 2013. Omnivores as seasonally important predators in a stream 601 food web. Freshwater Science 32:548-562. DOI: 10.1899/12-020.1.

602

603

604

605

606

607

608

609

610

611

612

613

614

615

616

617

Helm RC, Costa DP, DeBruyn TD, O'Shea TJ, Wells RS, Williams TM. 2015. Overview of Effects of Oil Spills on Marine Mammals. In: Handbook of Oil Spill Science and Technology. John Wiley \& Sons, Ltd, 455-475. DOI: 10.1002/9781118989982.ch18.

Hunter EA, Nibbelink NP, Alexander CR, Barrett K, Mengak LF, Guy RK, Moore CT, Cooper RJ. 2015. Coastal Vertebrate Exposure to Predicted Habitat Changes Due to Sea Level Rise. Environmental Management 56:1528-1537. DOI: 10.1007/s00267-015-0580-3.

Husseneder C, Donaldson JR, Foil LD. 2016. Impact of the 2010 Deepwater Horizon oil spill on population size and genetic structure of horse flies in Louisiana marshes. Scientific Reports 6:1-11. DOI: 10.1038/srep18968.

Hutchinson GE. 1959. Homage to Santa Rosalia or Why Are There So Many Kinds of Animals? The American Naturalist 93:145-159. DOI: 10.1086/282070.

Incardona JP, Vines CA, Anulacion BF, Baldwin DH, Day HL, French BL, Labenia JS, Linbo TL, Myers MS, Olson OP, Sloan CA, Sol S, Griffin FJ, Menard K, Morgan SG, West JE, Collier TK, Ylitalo GM, Cherr GN, Scholz NL. 2012. Unexpectedly high mortality in Pacific herring embryos exposed to the 2007 Cosco Busan oil spill in San Francisco Bay. Proceedings of the National Academy of Sciences 109:E51-E58. DOI: 10.1073/pnas.1108884109.

Peer) reviewing PDF | (2020:04:48011:1:1:NEW 28 Jan 2021) 
618 Inger R, Bearhop S. 2008. Applications of stable isotope analyses to avian ecology. Ibis 150:447-461.

619 DOI: 10.1111/j.1474-919X.2008.00839.x.

620 Jackson AL, Inger R, Parnell AC, Bearhop S. 2011. Comparing isotopic niche widths among and within

621 communities: SIBER - Stable Isotope Bayesian Ellipses in R: Bayesian isotopic niche metrics.

622 Journal of Animal Ecology 80:595-602. DOI: 10.1111/j.1365-2656.2011.01806.x.

623 Johnson JJ, Olin JA, Polito MJ. 2019. A multi-biomarker approach supports the use of compound-specific

624 stable isotope analysis of amino acids to quantify basal carbon source use in a salt marsh

625 consumer. Rapid Communications in Mass Spectrometry 33:1781-1791. DOI: 10.1002/rcm.8538.

626 Karlson AML, Gorokhova E, Elmgren R. 2015. Do deposit-feeders compete? Isotopic niche analysis of an

627 invasion in a species-poor system. Scientific Reports 5:srep09715. DOI: 10.1038/srep09715.

628 Kern RA, Shriver WG. 2014. Sea level rise and prescribed fire management: implications for seaside

629 sparrow population viability. Biological Conservation 173:24-31.

630 Kokaly RF, Couvillion BR, Holloway JM, Roberts DA, Ustin SL, Peterson SH, Khanna S, Piazza SC. 2013.

631 Spectroscopic remote sensing of the distribution and persistence of oil from the Deepwater

632 Horizon spill in Barataria Bay marshes. Remote Sensing of Environment 129:210-230. DOI:

$633 \quad$ 10.1016/j.rse.2012.10.028.

634 Kovalenko KE. 2019. Interactions among anthropogenic effects on aquatic food webs. Hydrobiologia

635 841:1-11. DOI: 10.1007/s10750-019-04018-x.

636 Kratina P, LeCraw RM, Ingram T, Anholt BR. 2012. Stability and persistence of food webs with omnivory:

637 Is there a general pattern? Ecosphere 3:art50. DOI: 10.1890/ES12-00121.1.

638 Krivan V, Diehl S. 2005. Adaptive omnivory and species coexistence in tri-trophic food webs. Theoretical

639 Population Biology 67:85-99. DOI: 10.1016/j.tpb.2004.09.003. 
640 Kroetz AM, Drymon JM, Powers SP. 2017. Comparative Dietary Diversity and Trophic Ecology of Two 641 Estuarine Mesopredators. Estuaries and Coasts 40:1171-1182. DOI: 10.1007/s12237-016-01886428.

643 Kruchek BL. 2004. Use of Tidal Marsh and Upland Habitats by the Marsh Rice Rat (Oryzomys palustris). $644 \quad$ Journal of Mammalogy 85:569-575. DOI: 10.1644/BEH-016.

645 Larson ER, Twardochleb LA, Olden JD. 2017. Comparison of trophic function between the globally 646 invasive crayfishes Pacifastacus leniusculus and Procambarus clarkii. Limnology 18:275-286. 647 DOI: 10.1007/s10201-016-0505-8.

648

649

650

651

652

653

654 655

656

657

658

659

660

661

662

MacArthur RH. 1972. Patterns in the distribution of species. In: MacArthur RH ed. Geographycal ecology. New York, NY: Princeton University Press,.

MacArthur RH, Pianka ER. 1966. On Optimal Use of a Patchy Environment. The American Naturalist 100:603-609.

Maia-Carneiro T, Motta-Tavares T, Rocha CFD. 2017. Partition of trophic niche dimensions of a pair of syntopic lizard species (Squamata, Tropidurus). The Herpetological Journal 27:143-150.

May RM, Arthur RHM. 1972. Niche Overlap as a Function of Environmental Variability. Proceedings of the National Academy of Sciences 69:1109-1113. DOI: 10.1073/pnas.69.5.1109.

McCall BD, Pennings SC. 2012. Disturbance and Recovery of Salt Marsh Arthropod Communities following BP Deepwater Horizon Oil Spill. PLOS ONE 7:e32735. DOI: 10.1371/journal.pone.0032735.

McCann MJ, Able KW, Christian RR, Fodrie FJ, Jensen OP, Johnson JJ, López-Duarte PC, Martin CW, Olin JA, Polito MJ, Roberts BJ, Ziegler SL. 2017. Key taxa in food web responses to stressors: the Deepwater Horizon oil spill. Frontiers in Ecology and the Environment 15:142-149. DOI: 10.1002/fee.1474. 
663 McClain CR, Nunnally C, Benfield MC. 2019. Persistent and substantial impacts of the Deepwater Horizon 664 oil spill on deep-sea megafauna. Royal Society Open Science 6:191164. DOI: $665 \quad 10.1098 /$ rsos.191164.

666

667

668

669

670

671

672

673

674

675

676

677

678

679

680

681

682

683

684

685

McNutt MK, Camilli R, Crone TJ, Guthrie GD, Hsieh PA, Ryerson TB, Savas O, Shaffer F. 2012. Review of flow rate estimates of the Deepwater Horizon oil spill. Proceedings of the National Academy of Sciences of the United States of America 109:20260-20267. DOI: 10.1073/pnas.1112139108.

Michel J, Owens EH, Zengel S, Graham A, Nixon Z, Allard T, Holton W, Reimer PD, Lamarche A, White M, Rutherford N, Childs C, Mauseth G, Challenger G, Taylor E. 2013. Extent and Degree of Shoreline Oiling: Deepwater Horizon Oil Spill, Gulf of Mexico, USA. PLOS ONE 8:e65087. DOI: 10.1371/journal.pone.0065087.

Mwijage AP, Shilla DA, Machiwa JF. 2018. Differences in trophic resources and niches of two juvenile predatory species in three Pangani estuarine zones, Tanzania: stomach contents and stable isotope approaches. Journal of Biological Research 25. DOI: 10.1186/s40709-018-0084-4.

Nakano S, Murakami M. 2001. Reciprocal subsidies: Dynamic interdependence between terrestrial and aquatic food webs. Proceedings of the National Academy of Sciences 98:166-170. DOI: 10.1073/pnas.98.1.166.

Nelson JA, Deegan L, Garritt R. 2015. Drivers of spatial and temporal variability in estuarine food webs. Marine Ecology Progress Series 533:67-77. DOI: 10.3354/meps11389.

Newsome SD, Rio CM del, Bearhop S, Phillips DL. 2007. A niche for isotopic ecology. Frontiers in Ecology and the Environment 5:429-436. DOI: 10.1890/060150.1.

Nixon Z, Zengel S, Baker M, Steinhoff M, Fricano G, Rouhani S, Michel J. 2016. Shoreline oiling from the Deepwater Horizon oil spill. Marine Pollution Bulletin 107:170-178. DOI: 10.1016/j.marpolbul.2016.04.003. 
686 O'Gorman EJ, Fitch JE, Crowe TP. 2012. Multiple anthropogenic stressors and the structural properties of 687 food webs. Ecology 93:441-448. DOI: 10.1890/11-0982.1.

688 Olin JA, Bergeon Burns CM, Woltmann S, Taylor SS, Stouffer PC, Bam W, Hooper-Bui L, Turner RE. 2017.

689 Seaside Sparrows reveal contrasting food web responses to large-scale stressors in coastal

690 Louisiana saltmarshes. Ecosphere 8:e01878. DOI: 10.1002/ecs2.1878.

691 Olin JA, Shipley ON, Cerrato RM, Nitschke P, Magen C, Frisk MG. 2020. Separation of realized ecological

692 niche axes among sympatric tilefishes provides insight into potential drivers of co-occurrence in

693 the NW Atlantic. Ecology and Evolution 10:10886-10898. DOI: 10.1002/ece3.6745.

694 Pennings SC, McCall BD, Hooper-Bui L. 2014. Effects of Oil Spills on Terrestrial Arthropods in Coastal

695 Wetlands. BioScience 64:789-795. DOI: 10.1093/biosci/biu118.

696 Perez-Umphrey AA, Bergeon Burns CM, Stouffer PC, Woltmann S, Taylor SS. 2018. Polycyclic aromatic

697 hydrocarbon exposure in seaside sparrows (Ammodramus maritimus) following the 2010

698 Deepwater Horizon oil spill. Science of The Total Environment 630:1086-1094. DOI:

$699 \quad$ 10.1016/j.scitotenv.2018.02.281.

700 Polito MJ, Brasso RL, Trivelpiece WZ, Karnovsky N, Patterson WP, Emslie SD. 2016. Differing foraging

701

702 strategies influence mercury $(\mathrm{Hg})$ exposure in an Antarctic penguin community. Environmental

Post DM. 2002. Using stable isotopes to estimate trophic position: models, methods, and assumptions.

706 Ecology 83:703-718.

707

Post W, Greenlaw JS. 2006. Nestling diets of coexisting salt marsh sparrows: Opportunism in a food-rich 708 environment. Estuaries and Coasts 29:765-775. DOI: 10.1007/BF02786527. 
709 Quezada-Romegialli C, Jackson AL, Hayden B, Kahilainen KK, Lopes C, Harrod C. 2018. tRophicPosition,

710 an r package for the Bayesian estimation of trophic position from consumer stable isotope

711 ratios. Methods in Ecology and Evolution 9:1592-1599. DOI: 10.1111/2041-210X.13009.

R Core Team. 2019. A language and environment for statistical computing. R Foundation for Statistical Computing, Vienna, Austria.

714

715

716

717

718

719

720

721

722

723

724

725

726

727

728

Rabalais NN, Turner RE. 2016. Effects of the Deepwater Horizon Oil Spill on Coastal Marshes and Associated Organisms. Oceanography 29:150-159.

Reuscher MG, Baguley JG, Conrad-Forrest N, Cooksey C, Hyland JL, Lewis C, Montagna PA, Ricker RW, Rohal M, Washburn T. 2017. Temporal patterns of Deepwater Horizon impacts on the benthic infauna of the northern Gulf of Mexico continental slope. PLOS ONE 12:e0179923. DOI: 10.1371/journal.pone.0179923.

Ridoux V, Lafontaine L, Bustamante P, Caurant F, Dabin W, Delcroix C, Hassani S, Meynier L, Silva VP da, Simonin S, Robert M, Spitz J, Canneyt OV. 2004. The impact of the "Erika" oil spill on pelagic and coastal marine mammals: Combining demographic, ecological, trace metals and biomarker evidences. Aquatic Living Resources 17:379-387. DOI: 10.1051/alr:2004031.

Rocha MP, Bini LM, Siqueira T. 2018. Predicting occupancy and abundance by niche position, niche breadth and body size in stream organisms. Oecologia 186:205-216.

Rose R, McGurk S. 2006. Year-round Diet of the Marsh Rice Rat, Oryzomys palustris, in Virginia Tidal Marshes. Virginia Journal of Science 57. DOI: 10.25778/4x69-4313.

Ruiter PC de, Wolters V, Moore JC. 2005. Dynamic Food Webs: Multispecies Assemblages, Ecosystem Development and Environmental Change. Elsevier.

Sharp HF. 1967. Food Ecology of the Rice Rat, Oryzomys Palustris (Harlan), in a Georgia Salt Marsh. Journal of Mammalogy 48:557-563. DOI: 10.2307/1377578. 
732 Soykan CU, Sabo JL. 2009. Spatiotemporal food web dynamics along a desert riparian-upland transition.

733 Ecography 32:354-368. DOI: 10.1111/j.1600-0587.2008.05615.x.

734 Svanbäck R, Bolnick D. 2005. Intraspecific competition affects the strength of individual specialization:

735 An optimal diet theory method. Evolutionary Ecology Research 7.

736

737

738

739

740

741

742

743

744

745

746

747

748

749

750

751

752

753

754 quantifying $n$-dimensional ecological niches and niche overlap. Ecology 96:318-324. DOI: 10.1890/14-0235.1.

Sykes Jr. PW. 1980. Decline and disappearance of the Dusky Seaside Sparrow from Merritt Island, Florida. American Birds 34:10.

Troisi G, Barton S, Bexton S. 2016. Impacts of oil spills on seabirds: Unsustainable impacts of nonrenewable energy. International Journal of Hydrogen Energy 41:16549-16555. DOI: 10.1016/j.ijhydene.2016.04.011.

Turner RE, Overton EB, Meyer BM, Miles MS, Hooper-Bui L. 2014a. Changes in the concentration and relative abundance of alkanes and PAHs from the Deepwater Horizon oiling of coastal marshes. Marine Pollution Bulletin 86:291-297. DOI: 10.1016/j.marpolbul.2014.07.003.

Turner RE, Overton EB, Meyer BM, Miles MS, McClenachan G, Hooper-Bui L, Engel AS, Swenson EM, Lee JM, Milan CS, Gao H. 2014b. Distribution and recovery trajectory of Macondo (Mississippi Canyon 252) oil in Louisiana coastal wetlands. Marine Pollution Bulletin 87:57-67. DOI: 10.1016/j.marpolbul.2014.08.011.

Turner RE, Rabalais NN, Overton EB, Meyer BM, McClenachan G, Swenson EM, Besonen M, Parsons ML, Zingre J. 2019. Oiling of the continental shelf and coastal marshes over eight years after the 2010 Deepwater Horizon oil spill. Environmental Pollution 252:1367-1376. DOI: 10.1016/j.envpol.2019.05.134. 
755

756

757

758

759

760

761

762

763

764

765

766

767

768

769

770

771

772

773

774

775

776

777

USFWS. 2011. Deepwater Horizon Bird Impact Data from the DOI-ERDC NRDA Database, 12 May 2011, http://www.fws.gov/home/dhoilspill/pdfs/Bird\%20Data\%20Species\%20Spreadsheet\%2005122011.pdf.

Wainright S, Weinstein M, Able K, Currin C. 2000. Relative importance of benthic microalgae, phytoplankton and the detritus of smooth cordgrass Spartina alterniflora and the common reed Phragmites australis to brackish-marsh food webs. Marine Ecology Progress Series 200:77-91. DOI: $10.3354 / \operatorname{meps} 200077$.

White HK, Hsing P-Y, Cho W, Shank TM, Cordes EE, Quattrini AM, Nelson RK, Camilli R, Demopoulos AWJ, German CR, Brooks JM, Roberts HH, Shedd W, Reddy CM, Fisher CR. 2012. Impact of the Deepwater Horizon oil spill on a deep-water coral community in the Gulf of Mexico. Proceedings of the National Academy of Sciences 109:20303-20308. DOI: 10.1073/pnas.1118029109.

Wigand C, McKinney RA, Cole ML, Thursby GB, Cummings J. 2007. Varying Stable Nitrogen Isotope Ratios of Different Coastal Marsh Plants and Their Relationships with Wastewater Nitrogen and Land Use in New England, USA. Environmental Monitoring and Assessment 131:71-81. DOI: 10.1007/s10661-006-9457-5.

Wolfe JL. 1982. Oryzomys palustris. American Society of Mammalogists 176:1-5.

Zengel S, Bernik BM, Rutherford N, Nixon Z, Michel J. 2015. Heavily Oiled Salt Marsh following the Deepwater Horizon Oil Spill, Ecological Comparisons of Shoreline Cleanup Treatments and Recovery. PLOS ONE 10:e0132324. DOI: 10.1371/journal.pone.0132324.

Zhang M, Wang Y, Gu B, Li Y, Zhu W, Zhang L, Yang L, Li X. 2019. Resources utilization and trophic niche between silver carp and bighead carp in two mesotrophic deep reservoirs. Journal of Freshwater Ecology 34:199-212. DOI: 10.1080/02705060.2018.1560368. 
778

779

780

781

782

783

784

785

786

787

788

789

790

791

792

793

794

795

796

797

798

799

800

801

802

803

804

805

806

807

808

809

810

\section{Figures}

Figure 1: Sampling locations (previously oiled versus non-oiled in the Port Sulphur area of Barataria Bay, Louisiana

Figure 2: Biplots (mean $\pm S D$ ) of isotope values $\left(\delta^{13} C\right.$ and $\left.\delta^{15} \mathrm{~N}\right)$ of (a) march rice rats (O. palustris) (b) seaside sparrows ( $A$. maritima) (c) primary consumers isotopic values relative to primary producer end members collected across all three years.

Figure 3: Modal $(95 \% \mathrm{Cl}$ ) trophic position (TP) [left panel] and posterior alpha [estimate of importance of terrestrial food] [right panel] of sympatric seaside sparrow (A. maritima) and marsh rice rat (O. palustris) assuming terrestrial and aquatic baselines. Asterisks indicate significant posterior differences (PP $>0.95$ ) between species.

Figure 4: Left panel: Stable isotope values $\left(\delta^{13} \mathrm{C}\right.$ and $\left.\delta^{15} \mathrm{~N}\right)$ and isotopic niche widths of sympatric seaside sparrow (A. maritima) and marsh rice rat (O. palustris) blood samples collected annually, as indicated by standard ellipse areas (SEAC). Right panel: Bayesian derived estimates of standard elliptical area $\left(\mathrm{SEA}_{b}\right)$ for each species with associated 50, 75 and 95\% credibility intervals.

\section{Tables}

Table 1: Sample size $(n)$, carbon $\left(\delta^{13} \mathrm{C}\right)$ and nitrogen $\left(\delta^{15} \mathrm{~N}\right)$ stable isotope values, trophic position (TP), posterior alpha $(\alpha)$ and isotopic trophic niche width $\left(S_{E} A_{b}\right)$ of seaside sparrows $(A$. maritima) and marsh rice rats (O. palustris) from oiled and unoiled sites, calculated by multivariate ellipse-based metrics and Bayesian estimates (SIBER R package; Jackson et al. 2011), across three study periods $(2015,2016,2017)$ from Barataria Bay, Louisiana. Different letters indicate significant differences in each year ( $P P>0.95$ ) based on the probability associated with paired comparisons for species at each treatment (oiled versus unoiled sites).

Table 2: Total trophic niche overlap (posterior mean and 95\% credible interval) among seaside sparrows (A. maritima) and marsh rice rats (O. palustris) collected between 2015 and 2017. Overlap is based upon ellipses encompassing $95 \%$ of the data and represents the percentage of the isotopic niche of species A within the isotopic niche of species B (Swanson et al., 2015). Two groups are considered to overlap asymmetrically when their lowest and highest estimates show no overlap. 
Figure 1

Sampling locations

Sampling locations (previously oiled versus non-oiled) in the Port Sulphur area of Barataria Bay, Louisiana

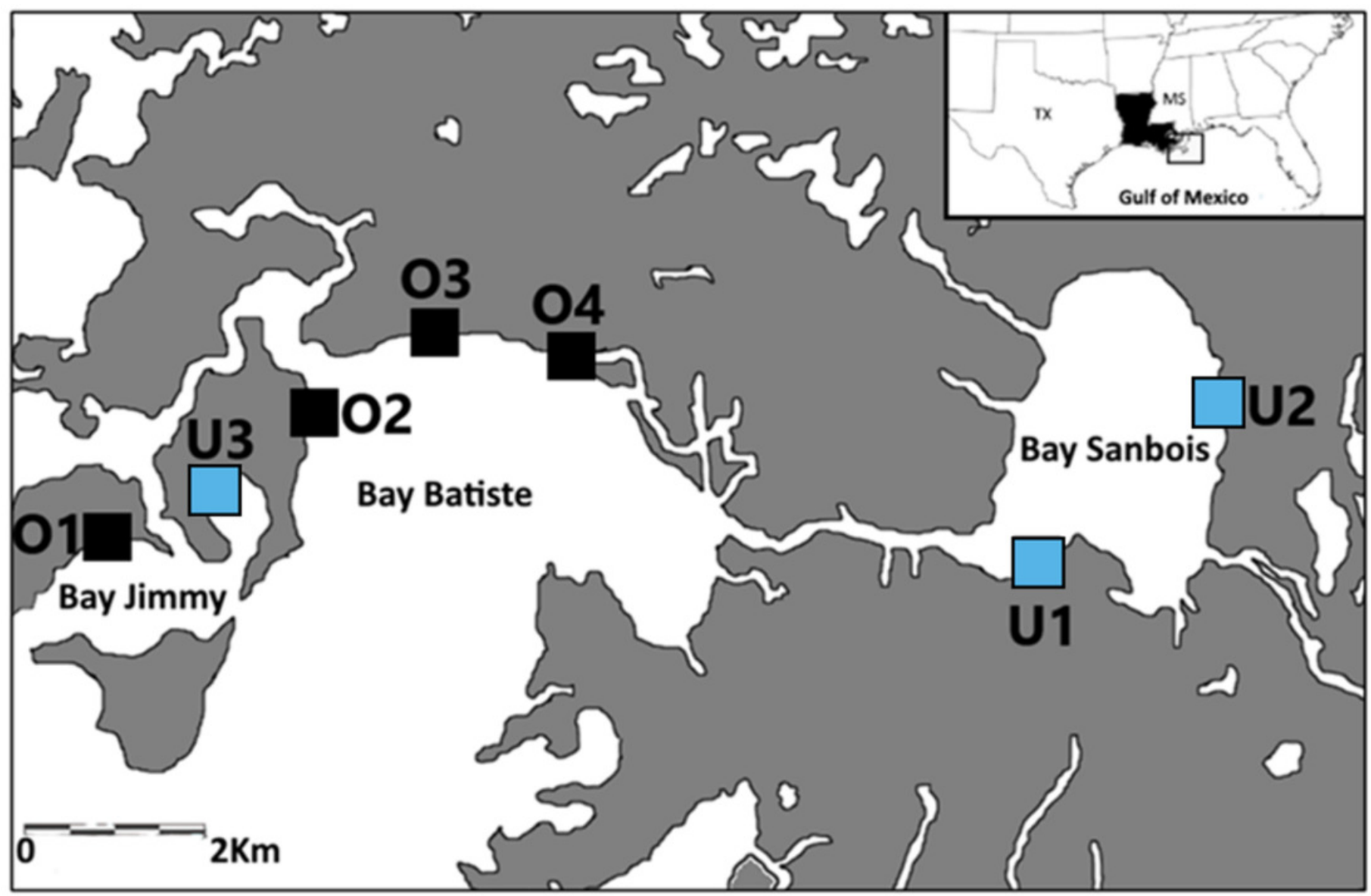


Figure 2

Biplot of stable isotope values of fauna and flora

Biplots (mean $\pm \mathrm{SD}$ ) of isotope values $\left(\delta^{13} \mathrm{C}\right.$ and $\delta^{15} \mathrm{~N}$ ) of (a) march rice rats (O. palustris) (b) seaside sparrows (A. maritima) (c) primary consumers isotopic values relative to primary producer end members collected across all three years. 


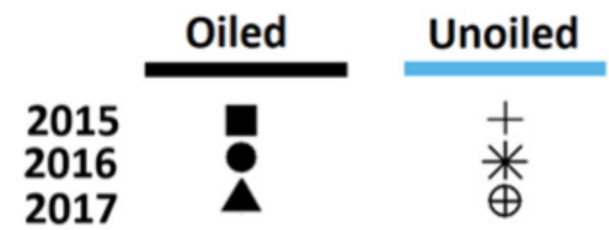

(a) Rats

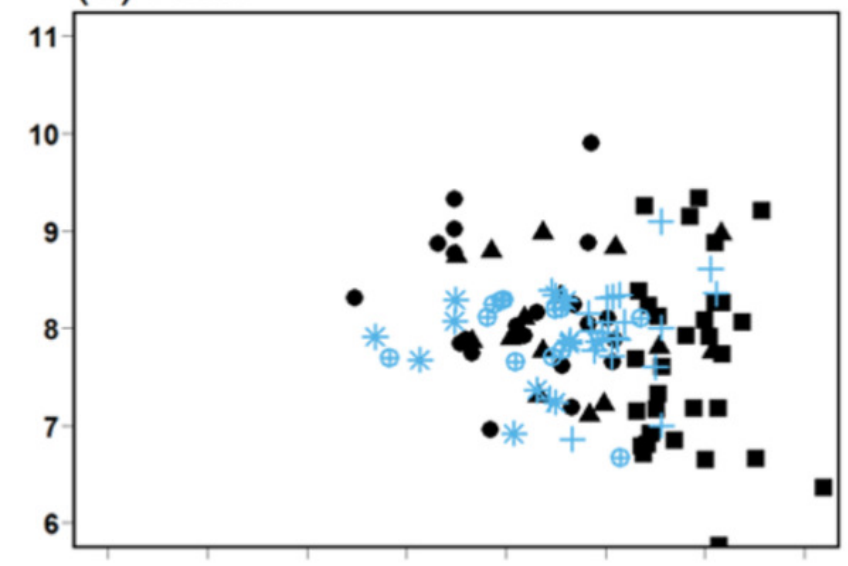

(b) Sparrows

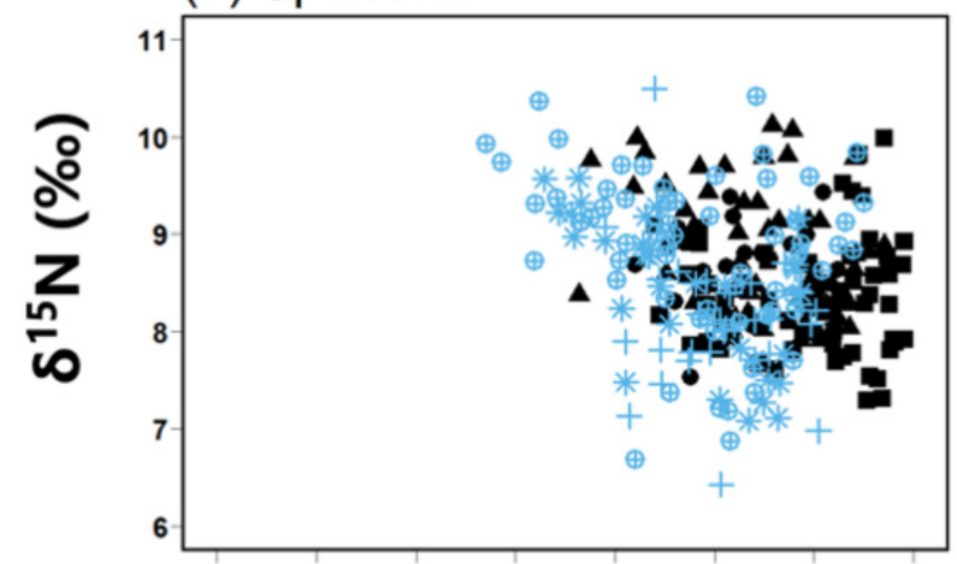

(c) Aquatic and terrestrial baseline

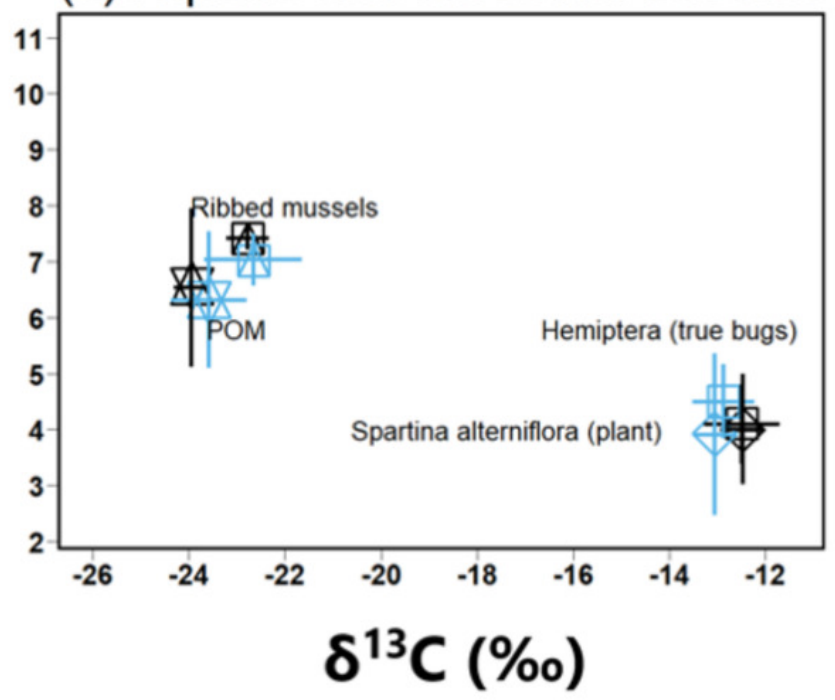




\section{Figure 3}

Trophic positions and posterior alpha of seaside sparrow and marsh rice rat

Modal $(95 \% \mathrm{Cl})$ trophic position (TP) [left panel] and posterior alpha [estimate of importance of terrestrial food] [right panel] of sympatric seaside sparrow (A. maritima) and marsh rice rat (O. palustris) assuming terrestrial and aquatic baselines. Asterisks indicate significant posterior differences (PP > 0.95) between species. 


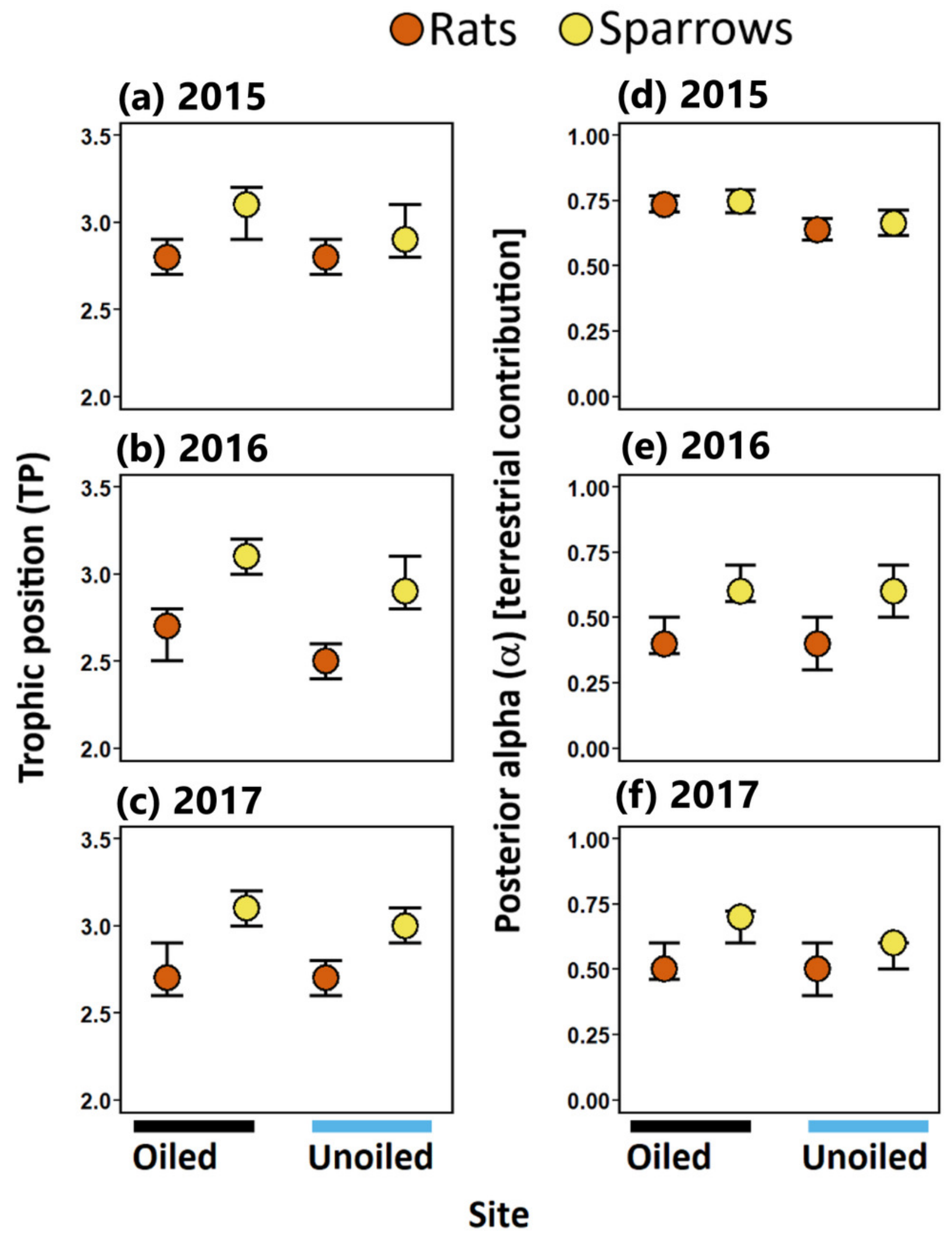




\section{Figure 4}

Stable isotope values and isotopic niche widths of seaside sparrow and marsh rice rat

Left panel: Stable isotope values $\left(\delta^{13} \mathrm{C}\right.$ and $\left.{ }^{15} \mathrm{~N}\right)$ and isotopic niche widths of sympatric seaside sparrow (A. maritima) and marsh rice rat (O. palustris) blood samples collected annually, as indicated by standard ellipse areas (SEAC). Right panel: Bayesian derived estimates of standard elliptical area $\left(\mathrm{SEA}_{b}\right)$ for each species with associated 50,75 and $95 \%$ credibility intervals. 


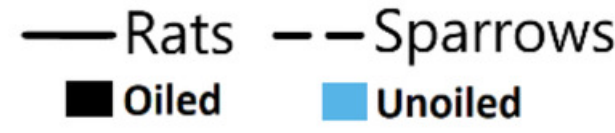

(a) 2015

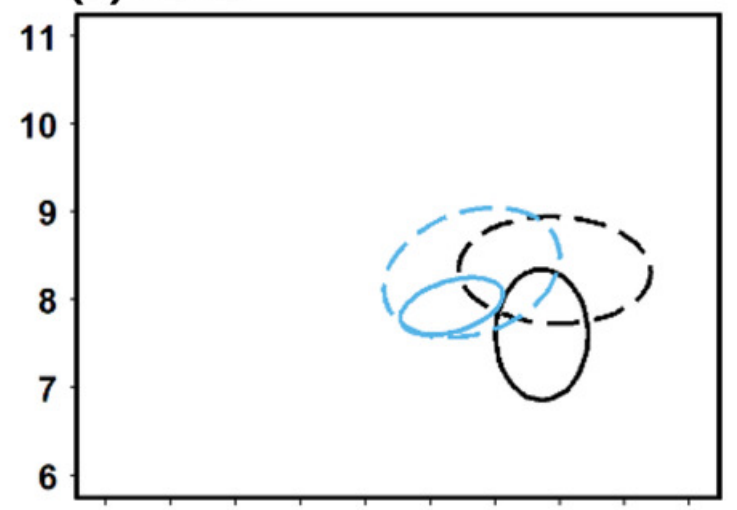

(b) 2016

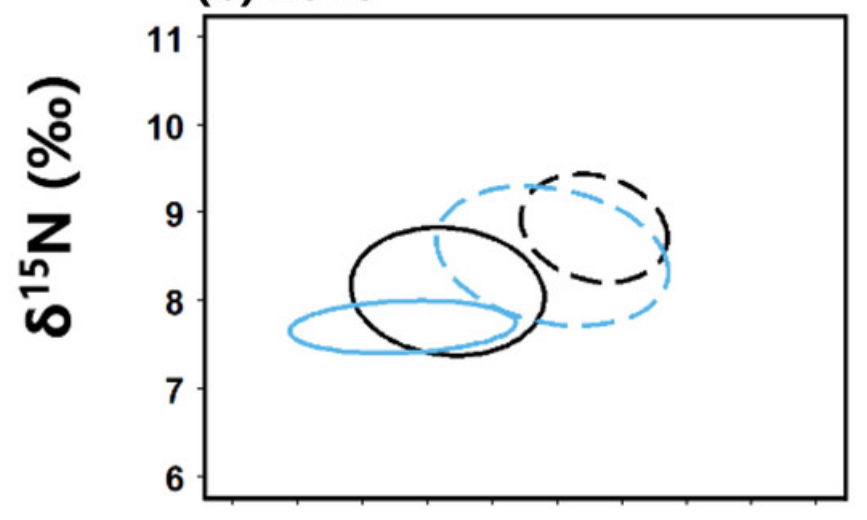

(c) 2017

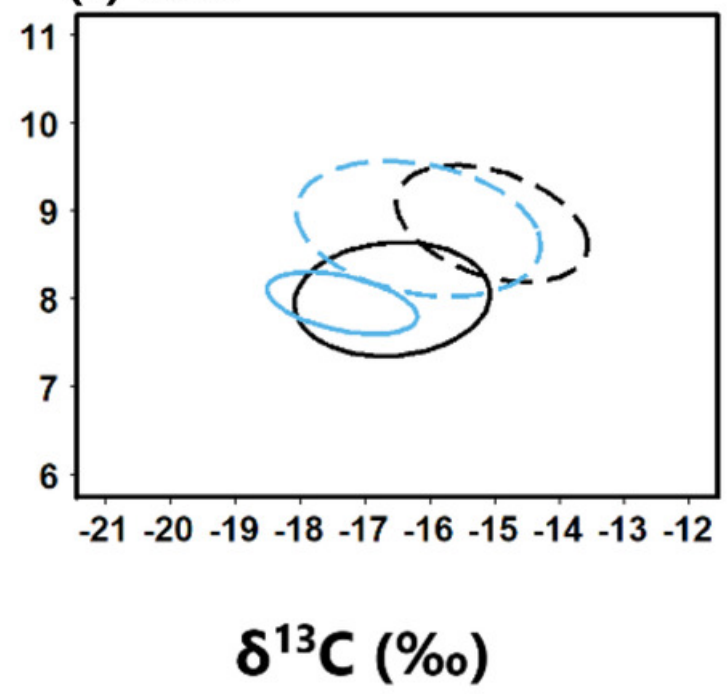

Oiled Unoiled

(d) 2015

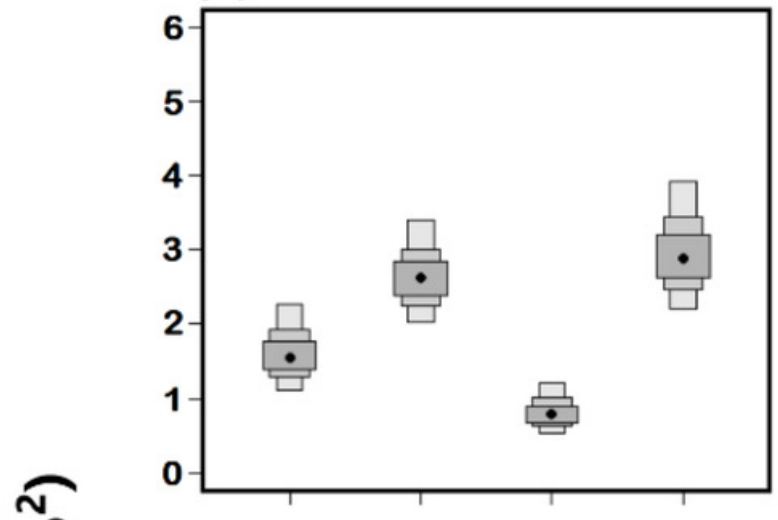

(e) 2016

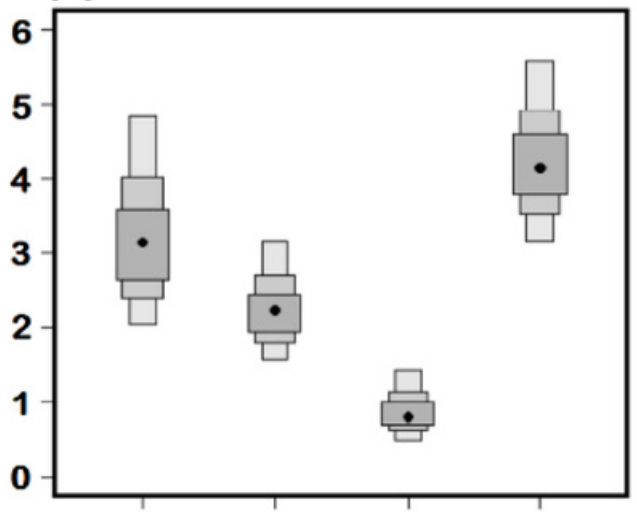

(f) 2017

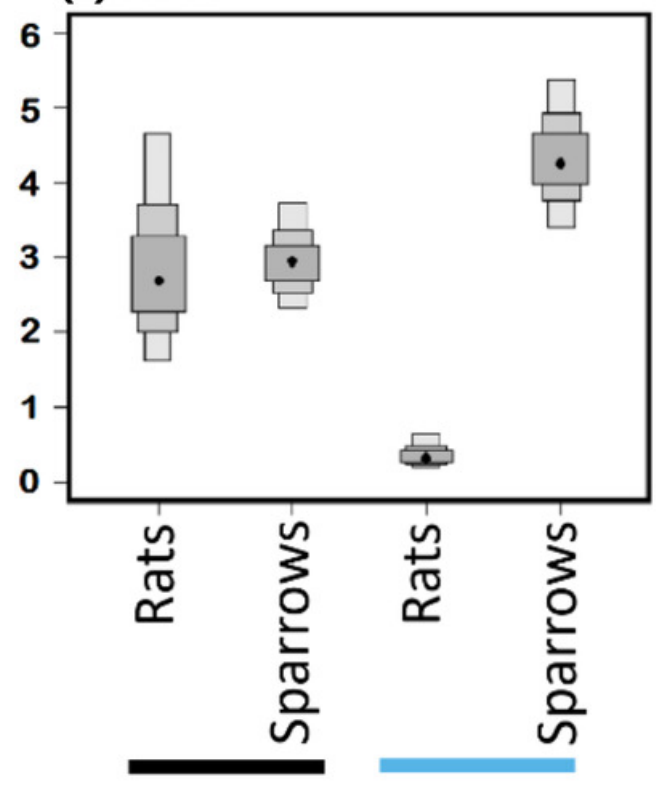




\section{Table $\mathbf{1}$ (on next page)}

Stable isotope values, trophic position, posterior alpha $(\alpha)$ and isotopic foraging niche width $\left(\mathrm{SEA}_{b}\right)$ of seaside sparrow and marsh rice rat

Sample size $(n)$, carbon $\left(\delta^{13} \mathrm{C}\right)$ and nitrogen $\left(\delta^{15} \mathrm{~N}\right)$ stable isotope values, trophic position (TP), posterior alpha $(\alpha)$ and isotopic trophic niche width $\left(\mathrm{SEA}_{b}\right)$ of seaside sparrows (A. maritima) and marsh rice rats ( $O$. palustris) from oiled and unoiled sites, calculated by multivariate ellipse-based metrics and Bayesian estimates (SIBER R package; Jackson et al. 2011), across three study periods $(2015,2016,2017)$ from Barataria Bay, Louisiana. Different letters indicate significant differences in each year ( $P P>0.95$ ) based on the probability associated with paired comparisons for species at each treatment (oiled versus unoiled sites). 
Table 1: Sample size $(n)$, carbon $\left(\delta^{13} \mathrm{C}\right)$ and nitrogen $\left(\delta^{15} \mathrm{~N}\right)$ stable isotope values, trophic position (TP), posterior alpha $(\alpha)$ and isotopic trophic niche width ( $\mathrm{SEA}_{b}$ ) of seaside sparrows (A. maritima) and marsh rice rats (O. palustris) from oiled and unoiled sites, calculated by multivariate ellipse-based metrics and Bayesian estimates (SIBER R package; Jackson et al. 2011), across three study periods (2015, 2016, 2017) from Barataria Bay, Louisiana. Different letters indicate significant differences in each year (PP > 0.95) based on the probability associated with paired comparisons for species at each treatment (oiled versus unoiled sites).

\begin{tabular}{|c|c|c|c|c|c|c|c|}
\hline \multirow[b]{2}{*}{ Year, Species } & \multirow[b]{2}{*}{ Group } & \multirow[b]{2}{*}{$\mathrm{n}$} & \multicolumn{2}{|c|}{ Mean \pm SD } & \multicolumn{3}{|c|}{ Modal (95\% Cl) } \\
\hline & & & $\delta^{13} \mathrm{C}$ & $\delta^{15} \mathrm{~N}$ & $\mathrm{TP}$ & $\alpha$ & $\mathrm{SEA}_{b}$ \\
\hline \multicolumn{8}{|l|}{2015} \\
\hline \multirow[t]{2}{*}{ Rats } & Oiled & 33 & $-14.2 \pm 0.7$ & $7.6 \pm 0.7$ & $2.8(2.7-2.9)^{a}$ & $0.7(0.7-0.8)^{a}$ & $1.6(1.4-2.4)^{a}$ \\
\hline & Unoiled & 23 & $-15.7 \pm 0.7$ & $7.9 \pm 0.3$ & $2.8(2.7-2.9)^{\mathrm{ab}}$ & $0.6(0.6-0.7)^{b}$ & $0.7(0.6-1.1)^{b}$ \\
\hline \multirow[t]{2}{*}{ Sparrows } & Oiled & 60 & $-14.1 \pm 1.5$ & $8.3 \pm 0.6$ & $3.0(2.9-3.2)^{b}$ & $0.7(0.7-0.8)^{a}$ & $2.7(2.5-3.5)^{c}$ \\
\hline & Unoiled & 48 & $-15.9 \pm 1.2$ & $8.1 \pm 0.7$ & $2.9(2.8-3.1)^{\mathrm{ab}}$ & $0.7(0.6-0.7)^{b}$ & $2.5(2.2-3.7)^{c}$ \\
\hline \multicolumn{8}{|l|}{2016} \\
\hline \multirow[t]{2}{*}{ Rats } & Oiled & 21 & $-17.7 \pm 1.4$ & $8.1 \pm 0.7$ & $2.7(2.5-2.8)^{a}$ & $0.4(0.4-0.5)^{a}$ & $3.1(2.7-4.9)^{a}$ \\
\hline & Unoiled & 15 & $-17.9 \pm 1.5$ & $7.7 \pm 0.3$ & $2.5(2.4-2.7)^{\mathrm{a}}$ & $0.4(0.3-0.5)^{a}$ & $1.4(1.2-2.6)^{b}$ \\
\hline \multirow[t]{2}{*}{ Sparrows } & Oiled & 33 & $-15.4 \pm 1.1$ & $8.6 \pm 0.4$ & $3.1(3.0-3.2)^{b}$ & $0.6(0.6-0.7)^{b}$ & $1.4(1.3-2.3)^{a}$ \\
\hline & Unoiled & 47 & $-16.6 \pm 1.6$ & $8.4 \pm 0.7$ & $2.9(2.8-3.1)^{b}$ & $0.6(0.5-0.7)^{b}$ & $3.1(2.7-4.5)^{c}$ \\
\hline \multicolumn{8}{|l|}{2017} \\
\hline \multirow[t]{2}{*}{ Rats } & Oiled & 15 & $-16.6 \pm 1.4$ & $8.0 \pm 0.6$ & $2.7(2.6-2.9)^{a}$ & $0.5(0.5-0.6)^{a}$ & $2.6(2.2-4.6)^{a}$ \\
\hline & Unoiled & 12 & $-17.4 \pm 1.1$ & $8.0 \pm 0.3$ & $2.7(2.6-2.8)^{a}$ & $0.5(0.4-0.5)^{a}$ & $1.0(0.8-1.9)^{b}$ \\
\hline \multirow[t]{2}{*}{ Sparrows } & Oiled & 67 & $-14.9 \pm 1.5$ & $8.8 \pm 0.6$ & $3.1(3.0-3.2)^{b}$ & $0.7(0.6-0.7)^{b}$ & $2.7(2.4-3.5)^{\mathrm{a}}$ \\
\hline & Unoiled & 75 & $-16.3 \pm 1.9$ & $8.8 \pm 0.8$ & $3.0(2.9-3.1)^{b}$ & $0.6(0.5-0.6)^{c}$ & $4.7(4.4-6.2)^{c}$ \\
\hline
\end{tabular}




\section{Table 2 (on next page)}

Trophic niche overlap among seaside sparrow and marsh rice rat

Total trophic niche overlap (posterior mean and 95\% credible interval) among seaside sparrows (A. maritima) and marsh rice rats (O. palustris) collected between 2015 and 2017. Overlap is based upon ellipses encompassing $95 \%$ of the data and represents the percentage of the isotopic niche of species A within the isotopic niche of species B (Swanson et al., 2015). Two groups are considered to overlap asymmetrically when their lowest and highest estimates show no overlap. 
1 Table 1: Total trophic niche overlap (posterior mean and 95\% credible interval) among seaside

2 sparrows (A. maritima) and marsh rice rats (O. palustris) collected between 2015 and 2017.

3 Overlap is based upon ellipses encompassing 95\% of the data and represents the percentage of

4 the isotopic niche of species A within the isotopic niche of species B (Swanson et al., 2015). Two

5 groups are considered to overlap asymmetrically when their lowest and highest estimates show

6 no overlap.

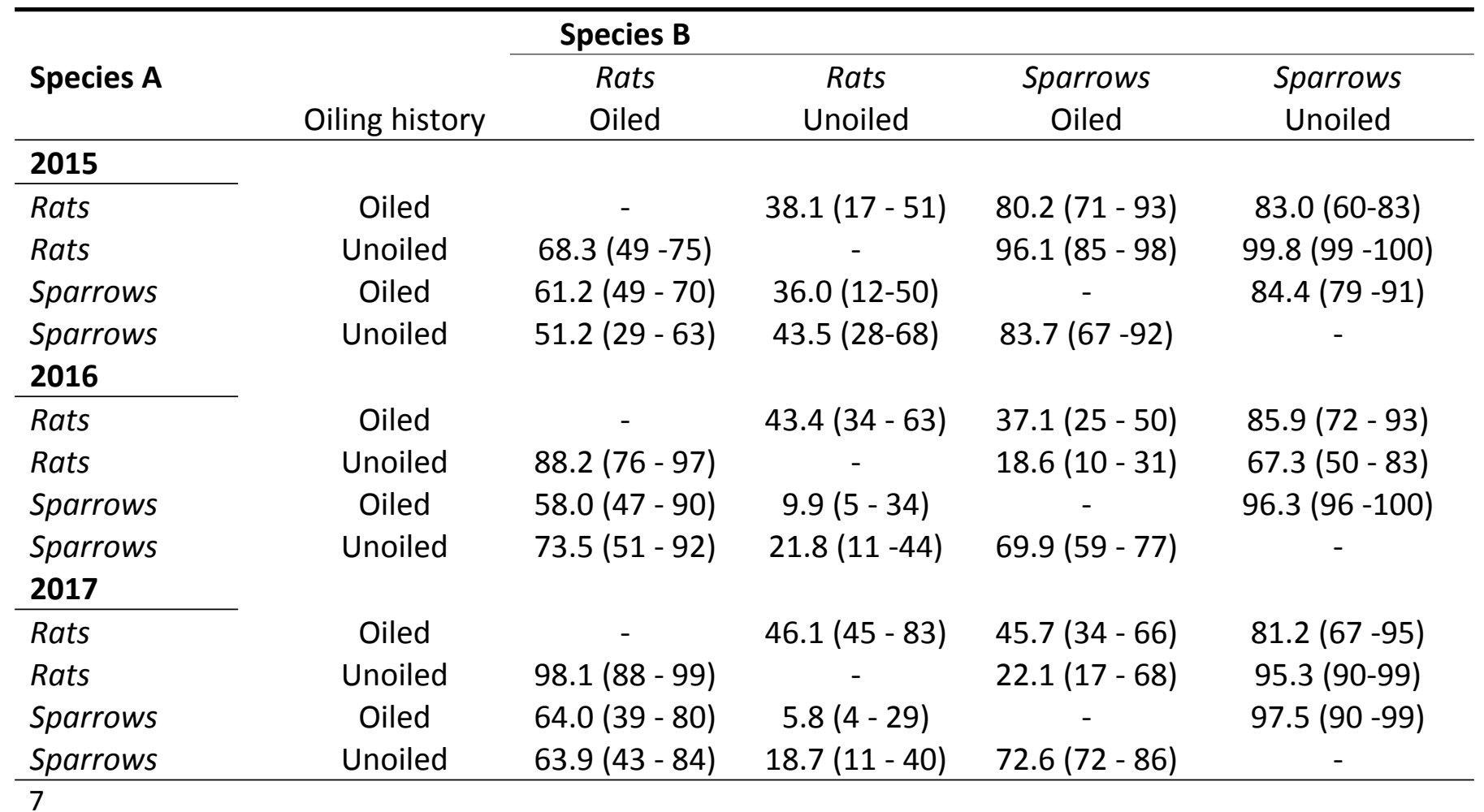

8

9

10

11

12 